Check for updates

Cite this: RSC Adv., 2019, 9, 18439

\section{Micranthanosides I and II, two novel 1,10- secograyanane diterpenoids and their antinociceptive analogues from the leaves and twigs of Rhododendron micranthum $\uparrow$}

\author{
Yuxun Zhu, Huimin Yan, \$ Xiaojing Wang, Zhaoxin Zhang, Huanping Zhang, \\ Lisha Chai, Li Li, (D) Jing Qu and Yong Li (D)*
}

\begin{abstract}
Micranthanosides I and II (1-2), two diterpenoid glucosides featuring a new 1,10-secograyanane skeleton, thirteen new diterpenoid glycosides (3-15), and 21 known analogues were obtained from the ethanol extract of the leaves and twigs of Rhododendron micranthum. Micranthanoside XII (12) represent the first example of 3,5-epoxy-4,5-seco-ent-kaurane diterpenoid. The structures of these compounds were determined by spectroscopic data analysis and quantum chemical calculations. To clarify the chemical basis and provide reference for rational use of this medicinal plant, the antinociceptive and the antiinflammatory activities of the compounds were tested. In the acetic acid-induced writhing test, compounds 17 and 19 showed significant antinociceptive activity at a dose of $3 \mathrm{mg} \mathrm{kg}^{-1}$ and compounds 2, 6 and 32 showed significant antinociceptive activity at a dose of $10 \mathrm{mg} \mathrm{kg}^{-1}$. Toxic reactions such as nausea and convulsion were observed when 17, 19, 29, and 31 at a dose of $10 \mathrm{mg} \mathrm{kg}^{-1}$ or 30 and 33 at a dose of $1 \mathrm{mg} \mathrm{kg}^{-1}$ were administered. The anti-inflammatory activities of the isolated compounds were evaluated by measuring the inhibitory effects of LPS-induced NO production in BV2 cells. At $10 \mu \mathrm{M}$, micranthanoside IX (9) and rhodomicranoside F (26) showed moderate anti-inflammatory activities with inhibition rates of $56.31 \%$ and $72.43 \%$, respectively.
\end{abstract}

Received 7th March 2019 Accepted 22nd May 2019 DOI: $10.1039 / c 9 r a 01736 d$ rsc.li/rsc-advances

\section{Introduction}

Natural products have been important sources for drug discovery. ${ }^{\mathbf{1 , 2}}$ Evidence suggests that natural products continue to play a significant role in the area of genomics. ${ }^{3}$ Rhododendron micranthum Turcz. (Ericaceae), commonly known as "zhaoshanbai", is widely distributed in northern China. This plant is used traditionally as a medicine for the treatment of postpartum arthralgia and chronic bronchitis. ${ }^{4}$ The extract of $R$. micranthum has also been developed as a drug for clinical use. Meanwhile, cases of clinical poisoning with "zhaoshanbai" have occasionally been reported. ${ }^{5,6}$ In these cases, some patients were found to have side effects and toxic symptoms such as nausea, epigastric pain and burning, hypotension, bradycardia, and dizziness. $^{7}$ Although andromedotoxin from $R$. micranthum has been reported to be toxic, ${ }^{8}$ the chemical basis of its

State Key Laboratory of Bioactive Substance and Function of Natural Medicines, Institute of Materia Medica, Chinese Academy of Medical Sciences, Peking Union Medical College, Beijing 100050, People's Republic of China. E-mail: liyong@imm. ac.cn

$\dagger$ Electronic supplementary information (ESI) available: 1D and 2D NMR, HRESIMS, CD, GC analysis, and IR. See DOI: 10.1039/c9ra01736d

\$ Y.-X. Z. and H.-M. Y. contributed equally. antinociceptive and anti-inflammatory effects as well as its toxicity is still not well understood.

Previously, we have reported antinociceptive grayanane diterpenoids with structural diversity from $R$. molle, $R$. decorum, and Pieris formosa. Among them, rhodojaponin III and VI, craiobiotoxin IX, and pieristoxin $\mathrm{N}$ and $\mathrm{P}$ were found to be highly potent in several antinociceptive models. ${ }^{9-12}$ In addition, micranthanoside A, grayanotoxins I, and III in $R$. micranthum were reported to have significant antinociceptive activity at a dose of $0.2 \mathrm{mg} \mathrm{kg} \mathrm{kg}^{-1}$ in the acetic acid-induced writhing test. $^{13,14}$ In order to provide chemical evidence for rational application of "zhaoshanbai" and discover structurally interesting lead compounds, leaves and twigs of $R$. micranthum (107.5 kg) were collected from Shandong Province. An ethanol extract of the leaves and twigs of $R$. micranthum was investigated and afforded 36 diterpenoids, including 15 new analogues (115) (Fig. 1). The isolation, structural elucidation, antinociceptive activities, and anti-inflammatory activities of these compounds are described herein.

\section{Results and discussion}

Compound 1 (micranthanoside I) was obtained as white powder and was found to have a molecular formula of $\mathrm{C}_{26} \mathrm{H}_{42} \mathrm{O}_{8}$ based 

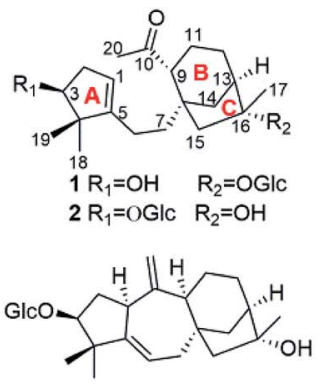

7

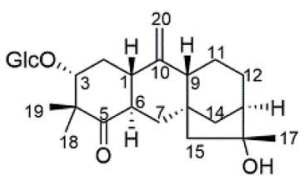

15

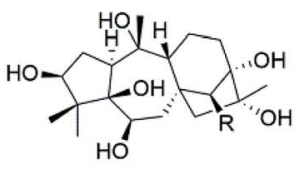

$27 \mathrm{R}=\mathrm{OAC}$

$28 \mathrm{R}=\mathrm{OH}$
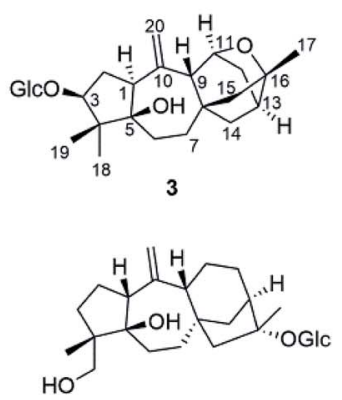

8

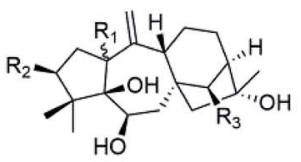

$20 \mathrm{R}_{1}=\alpha-\mathrm{H} \quad \mathrm{R}_{2}=\mathrm{OH} \quad \mathrm{R}_{3}=\mathrm{OAC}$ $21 \mathrm{R}_{1}=\beta-\mathrm{H} \quad \mathrm{R}_{2}=O$ OGlc $\mathrm{R}_{3}=\mathrm{H}$ $22 \mathrm{R}_{1}=\alpha-\mathrm{H} \quad \mathrm{R}_{2}=\mathrm{OH} \quad \mathrm{R}_{3}=\mathrm{OH}$ $23 \mathrm{R}_{1}=\alpha-\mathrm{H} \quad \mathrm{R}_{2}=\mathrm{OGIC} \quad \mathrm{R}_{3}=\mathrm{H}$

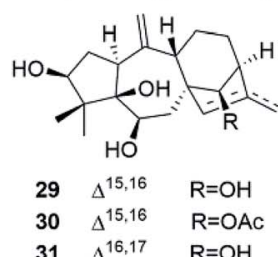

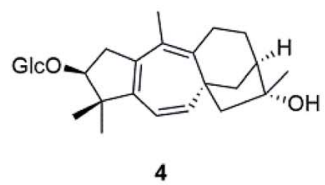

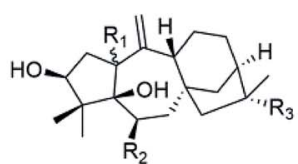

$9 \quad \mathrm{R}_{1}=\alpha-\mathrm{H} \quad \mathrm{R}_{2}=\mathrm{H} \quad \mathrm{R}_{3}=\mathrm{OGlc}$ $10 \mathrm{R}_{1}=\beta-\mathrm{H} \quad \mathrm{R}_{2}=\mathrm{H} \quad \mathrm{R}_{3}=\mathrm{OGlC}$ $11 \mathrm{R}_{1}=\alpha-\mathrm{H} \quad \mathrm{R}_{2}=\mathrm{OGlc} \mathrm{R}_{3}=\mathrm{OH}$ $16 \mathrm{R}_{1}=\alpha-\mathrm{H} \quad \mathrm{R}_{2}=\mathrm{OH} \quad \mathrm{R}_{3}=\mathrm{OGIC}$ $17 \mathrm{R}_{1}=\alpha-\mathrm{H} \quad \mathrm{R}_{2}=\mathrm{OH} \quad \mathrm{R}_{3}=\mathrm{OH}$ $18 \mathrm{R}_{1}=\beta-\mathrm{H} \quad \mathrm{R}_{2}=\mathrm{OH} \quad \mathrm{R}_{3}=\mathrm{OH}$ $19 \mathrm{R}_{1}=\beta-H \quad \mathrm{R}_{2}=\mathrm{H} \quad \mathrm{R}_{3}=\mathrm{OH}$

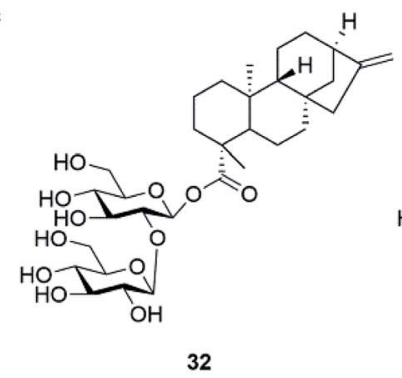

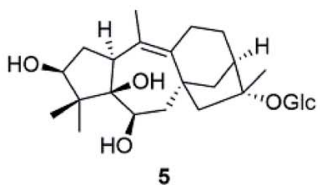
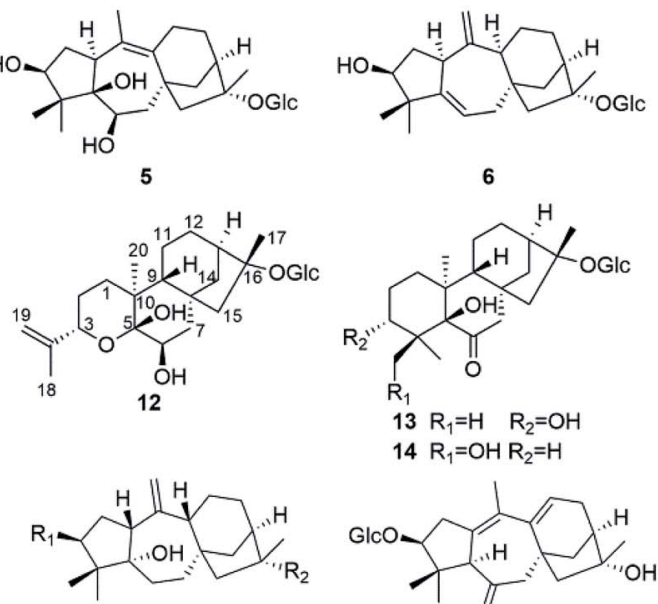

$24 \mathrm{R}_{1}=\mathrm{OH} \quad \mathrm{R}_{2}=\mathrm{OGIC}$ $25 \mathrm{R}_{1}=\mathrm{OGI} \quad \mathrm{R}_{2}=\mathrm{OH}$
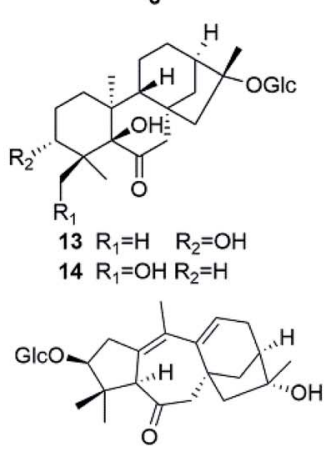

26

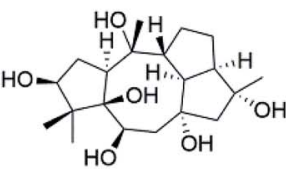

33

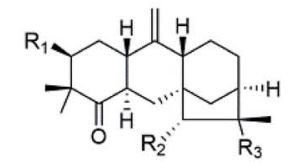

$34 \mathrm{R}_{1}=\mathrm{OGIC} \quad \mathrm{R}_{2}=\mathrm{OH} \quad \mathrm{R}_{3}=\mathrm{OH}$ $35 \mathrm{R}_{1}=\mathrm{OGIC} \quad \mathrm{R}_{2}=\mathrm{H} \quad \mathrm{R}_{3}=\mathrm{H}$ $36 \mathrm{R}_{1}=\mathrm{OH} \quad \mathrm{R}_{2}=\mathrm{H} \quad \mathrm{R}_{3}=\mathrm{OGlC}$

Fig. 1 Chemical structures of compounds 1-36.

on the (+)-HRESIMS ion at $m / z 505.2786[\mathrm{M}+\mathrm{Na}]^{+}$(calcd. for $\mathrm{C}_{26} \mathrm{H}_{42} \mathrm{O}_{8} \mathrm{Na}$, 505.2772), corresponding to six indices of hydrogen deficiency (IHD). Its IR spectrum suggested the presence of hydroxy $\left(3368 \mathrm{~cm}^{-1}\right)$ and carbonyl $\left(1700 \mathrm{~cm}^{-1}\right)$ functionalities. The ${ }^{1} \mathrm{H}$ NMR (Table 1) data showed resonances of four methyl groups $\left(\delta_{\mathrm{H}} 1.20,1.28,1.64\right.$, and 2.17), a glucose unit $\left(\delta_{\mathrm{H}} 3.93,3.97,4.24,4.25,4.38,4.51\right.$, and 5.01), and an olefinic proton at $\delta_{\mathrm{H}} 5.27$. The ${ }^{13} \mathrm{C}$ NMR data (Table 4), HSQC, and DEPT spectra of $\mathbf{1}$ exhibited 26 carbon resonances, including four methyls, eight methylenes, nine methines, and five $\mathrm{sp}^{3}$ carbons. A sugar unit, a carbonyl group, and a double bond account for three of the IHDs, which suggest that the remaining part is consisting of three rings.

The COSY (Fig. 2a) and HSQC spectra established four fragments: $\mathrm{CH}(\mathrm{OH})-\mathrm{CH}_{2}-\mathrm{CH}, \mathrm{CH}_{2}-\mathrm{CH}_{2}, \mathrm{CH}-\mathrm{CH}_{2}-\mathrm{CH}_{2}-\mathrm{CH}-$ $\mathrm{CH}_{2}$, and $\mathrm{CH}-\mathrm{CH}(\mathrm{OH})-\mathrm{CH}(\mathrm{OH})-\mathrm{CH}(\mathrm{OH})-\mathrm{CH}-\mathrm{CH}_{2}(\mathrm{OH})$. Fragment a and the HMBC correlations from two gem-dimethyl singlets $\left(\mathrm{H}_{3}-18\right.$ and $\left.\mathrm{H}_{3}-19\right)$ to carbons $\mathrm{C}-3, \mathrm{C}-4$, and $\mathrm{C}-5$ allowed the five-membered carbon ring (ring A in Fig. 1) to be defined. The HMBC correlations from $\mathrm{H}-6$ to C- 1 and from $\mathrm{H}_{2}-7$ to $\mathrm{C}-5$ connected C-5 directly to fragment b via C-6. HMBC correlations from $\mathrm{H}-9$ and $\mathrm{H}-14$ (two ends of fragment c) to $\delta_{\mathrm{C}} 47.3$ (C8), from $\mathrm{H}_{2}-12$ to quaternary carbon at $\delta_{\mathrm{C}} 88.1$ (C-16), as well as correlations from $\mathrm{H}_{2}-15$ to $\mathrm{C}-8, \mathrm{C}-9, \mathrm{C}-14$, and $\mathrm{C}-16$ revealed a bicyclo[3.2.1]octane ring system (rings $\mathrm{B} / \mathrm{C}$ ). The $\mathrm{HMBC}$ correlations from $\mathrm{H}_{3}-20\left(\delta_{\mathrm{H}} 2.17\right)$ to $\mathrm{C}-9\left(\delta_{\mathrm{C}} 53.6\right) / \mathrm{C}-10\left(\delta_{\mathrm{C}} 212.9\right)$ indicated that C-9 was connected to C-10. Finally, key HMBC correlations from $\mathrm{H}-1$ to $\mathrm{C}-6$ and from $\mathrm{H}-9$ and $\mathrm{H}_{2}-15$ to C-7 confirmed the connection of C-5 and C-8 via fragment $\mathrm{b}$. The glucose unit was placed at C-16 based on the HMBC correlation from $\mathrm{H}-\mathbf{1}^{\prime}$ to $\mathrm{C}-16$. As a result, the planar structure of 1 was fully established, which is the first example of a 1,10-secograyanane.

The relative configuration of $\mathbf{1}$ was deduced by the NOESY experiments. Ring $\mathrm{A}$ and rings $\mathrm{B} / \mathrm{C}$ were connected through two methylenes, which should theoretically provide molecular flexibility and complicate the stereochemical analysis. The NOESY correlations of $\mathrm{H}_{3}-18 / \mathrm{H}-6 \alpha$ and $\mathrm{H}-14 \alpha / \mathrm{H}-7 \alpha$ ( $\alpha$-side) and $\mathrm{H}_{3}-19$ / $\mathrm{H}-6 \beta$ and $\mathrm{H}-14 \beta / \mathrm{H}-7 \beta$ ( $\beta$-side) indicated that bulky substituents at C-5 and C-8 restrict the rotation of the C-6/C-7 bond and led to a preferential conformation in pyridine- $d_{5}$ (room temperature) in which C-5 and C-8 were in the anti-position (Fig. 2b). The NOESY correlations of $\mathrm{H}-3 / \mathrm{H}_{3}-18, \mathrm{H}_{3}-18 / \mathrm{H}-6 \alpha, \mathrm{H}_{3}-19 / \mathrm{H}-6 \beta$, $\mathrm{H}-6 \beta / \mathrm{H}-9, \mathrm{H}-9 / \mathrm{H}-15 \beta$, and $\mathrm{H}_{3}-17 / \mathrm{H}-12 \beta$ indicated that $\mathrm{H}-3$ is $\alpha-$ oriented and $\mathrm{H}-9$ and $\mathrm{CH}_{3}-17$ are $\beta$-oriented. The anomeric proton at $\mathrm{H}-1^{\prime}\left(\delta_{\mathrm{H}} 5.01\right)$ showed a large coupling constant (7.8 $\mathrm{Hz}$ ), indicating that the glucose unit is in $\beta$-configuration. Acid hydrolysis and GC analysis of the sugar moiety of $\mathbf{1}$ confirmed that the sugar was D-glucose (retention time: $29.35 \mathrm{~min}$ ). To determine the absolute configuration of $\mathbf{1}$, the ECD spectra for 1a $\left(3 S, 8 S, 9 R, 13 R, 16 R, 1^{\prime} S, 2^{\prime} R, 3^{\prime} S, 4^{\prime} S, 5^{\prime} R\right)$ and its enantiomer $\mathbf{1 b}$ were calculated using time-dependent density functional theory calculations at the B3LYP/6-31+G(d,p) level in methanol. ${ }^{15}$ The measured CD spectrum of $\mathbf{1}$ agreed well with the calculated ECD 
Table $1{ }^{1} \mathrm{H}$ NMR spectroscopic data for compounds $1-7$ in pyridine- $d_{5}(\delta$ in ppm, $J$ in $\mathrm{Hz}$ )

\begin{tabular}{|c|c|c|c|c|c|c|c|}
\hline No & $\mathbf{1}^{a}$ & $2^{b}$ & $3^{b}$ & $4^{b}$ & $5^{b}$ & $6^{a}$ & $7^{a}$ \\
\hline 1 & 5.27, brs & 5.16 , brs & $3.39, \mathrm{~m}$ & - & $3.51, \mathrm{t}(9.4)$ & $3.34, \mathrm{~d}(8.5)$ & $3.29, \mathrm{~d}(9.3)$ \\
\hline 2 & $2.46, \mathrm{~m}$ & $2.55, \mathrm{~m}$ & $2.33, \mathrm{~m}$ & $2.87, \mathrm{dd}(16.1,6.8)$ & $2.41, \mathrm{~m}$ & $2.19, \mathrm{~m}$ & $2.38, \mathrm{~m}$ \\
\hline \multirow[t]{2}{*}{3} & $4.26, \mathrm{~m}$ & $4.24, \mathrm{t}(7.2)$ & $4.2, \mathrm{~m}$ & $4.35, \mathrm{t}(7.0)$ & $3.87, \mathrm{~m}$ & $4.38, \mathrm{brs}$ & $4.40, \mathrm{~m}$ \\
\hline & - & - & - & - & - & - & - \\
\hline 4 & - & - & - & - & - & - & - \\
\hline & $2.29, \mathrm{t}(13.5)$ & $2.15, \mathrm{~m}$ & $1.73, \mathrm{~m}$ & - & - & - & - \\
\hline \multirow[t]{2}{*}{7} & $1.78, \mathrm{~m}$ & $1.65, \mathrm{~m}$ & $1.24, \mathrm{~d}(11.1)$ & $5.55, \mathrm{~d}(9.8)$ & $2.39, \mathrm{~m}$ & $2.40, \mathrm{~m}$ & $2.18, \mathrm{~m}$ \\
\hline & $1.91, \mathrm{~m}$ & $1.88, \mathrm{~m}$ & $2.11, \mathrm{~m}$ & & $2.53, \mathrm{~m}$ & $2.52, \mathrm{~m}$ & $2.51, \mathrm{~m}$ \\
\hline 8 & - & - & - & - & - & - & - \\
\hline 9 & 2.76, brs & $2.73, \mathrm{~d}(7.2)$ & 2.90, brs & - & - & $2.18, \mathrm{~m}$ & $2.15, \mathrm{~m}$ \\
\hline $\begin{array}{l}10 \\
11\end{array}$ & - & - & - & - & - & - & - \\
\hline 13 & $2.53, \mathrm{brs}$ & 2.19, brs & $2.19, \mathrm{t}(6.6)$ & $2.32, \mathrm{~m}$ & $2.54, \mathrm{brs}$ & 2.47, brs & $2.15, \mathrm{~m}$ \\
\hline \multirow[t]{2}{*}{14} & $2.36, \mathrm{~m}$ & 2.30, dd $(11.0,4.7)$ & $1.41, \mathrm{~m}$ & $2.13, \mathrm{~d}(11.0)$ & $1.58, \mathrm{~d}(10.8)$ & $1.55, \mathrm{~d}(11.1)$ & $1.62, \mathrm{~d}(10.1)$ \\
\hline & $2.38, \mathrm{~m}$ & $2.43, \mathrm{~d}(11.2)$ & 1.98, dd $(11.7,3.3)$ & $2.39, \mathrm{dd}(11.0,4.7)$ & $2.71, \mathrm{~m}$ & $2.23, \mathrm{~m}$ & $2.14, \mathrm{~m}$ \\
\hline \multirow[t]{2}{*}{15} & $1.55, \mathrm{~m}$ & $1.67, \mathrm{~d}(14.0)$ & $1.24, \mathrm{~d}(11.1)$ & $1.60, \mathrm{~d}(12.2)$ & $2.41, \mathrm{~m}$ & $1.74, \mathrm{~d}(12.8)$ & $1.92, \mathrm{brs}$ \\
\hline & $2.37, \mathrm{~m}$ & $2.04, \mathrm{~d}(13.8)$ & 1.79, dd $(11.1,3.3)$ & $2.09, \mathrm{~d}(12.5)$ & $2.90, \mathrm{~d}(15.2)$ & $2.26, \mathrm{~d}(14.2)$ & $1.92, \mathrm{brs}$ \\
\hline 16 & - & - & - & - & - & - & - \\
\hline 17 & $1.64, \mathrm{~s}$ & $1.58, \mathrm{~s}$ & $1.43, \mathrm{~s}$ & $1.39, \mathrm{~s}$ & $1.67, \mathrm{~s}$ & $1.59, \mathrm{~s}$ & $1.54, \mathrm{~s}$ \\
\hline \multirow[t]{2}{*}{18} & $1.20, \mathrm{~s}$ & $1.21, \mathrm{~s}$ & $0.99, \mathrm{~s}$ & $1.34, \mathrm{~s}$ & $0.88, \mathrm{~s}$ & $1.17, \mathrm{~s}$ & $1.28, \mathrm{~s}$ \\
\hline & - & - & - & & & & - \\
\hline 19 & $1.28, \mathrm{~s}$ & $1.27, \mathrm{~s}$ & $1.48, \mathrm{~s}$ & $1.31, \mathrm{~s}$ & $1.32, \mathrm{~s}$ & $1.22, \mathrm{~s}$ & $1.28, \mathrm{~s}$ \\
\hline \multirow[t]{2}{*}{20} & $2.17, \mathrm{~s}$ & $2.15, \mathrm{~s}$ & $5.05, \mathrm{~s}$ & $1.79, \mathrm{~s}$ & $1.84, \mathrm{~s}$ & $4.96, \mathrm{~s}$ & $5.00, \mathrm{~s}$ \\
\hline & - & - & $5.47, \mathrm{~s}$ & - & - & $5.09, \mathrm{~s}$ & $5.20, \mathrm{~s}$ \\
\hline
\end{tabular}

${ }^{a}$ Recorded at $500 \mathrm{MHz}{ }^{b}$ Recorded at $600 \mathrm{MHz}$.

of $\mathbf{1 a}$ and is the opposite of that of $\mathbf{1 b}$ (Fig. 3). Thus, the absolute configuration of $\mathbf{1}$ was established.

Compound 2 (micranthanoside II) was obtained as white powder and was found to have a molecular formula of $\mathrm{C}_{26} \mathrm{H}_{42} \mathrm{O}_{8}$. Its NMR data were highly similar to those of 1 except for the variations in the chemical shifts of C-3 $\left(\Delta \delta_{\mathrm{C}}+8.3\right)$ and C$16\left(\Delta \delta_{\mathrm{C}}-8.9\right)$, suggesting that the glucose unit was placed at $\mathrm{C}$ 3. The key HMBC correlation from $\mathrm{H}-\mathbf{1}^{\prime}$ to $\mathrm{C}-3$ confirmed the above assignment. The relative configuration of 2 was assigned the same as 1 by its NOESY correlations of $\mathrm{H}-3 / \mathrm{H}_{3}-18$ and $\mathrm{H}-9 / \mathrm{H}-$ $15 \beta$. The anomeric proton at $\mathrm{H}^{-1}\left(\delta_{\mathrm{H}} 4.70\right)$ showed a large coupling constant $(7.8 \mathrm{~Hz})$, indicating that the glucose unit is in $\beta$-configuration. Acid hydrolysis and GC analysis of the sugar moiety of 2 confirmed that the sugar was D-glucose (retention time: $29.32 \mathrm{~min}$ ). The CD spectrum of 2 was consistent with that of 1, showing a negative cotton effect at $303 \mathrm{~nm}$ (ESI Fig. S163 and $S 164 \dagger)$. Thus, the absolute configuration of 2 was assigned as $\left(3 S, 8 S, 9 R, 13 R, 16 R, 1^{\prime} R, 2^{\prime} R, 3^{\prime} S, 4^{\prime} S, 5^{\prime} R\right)$.
Compound 3 (micranthanoside III) has a molecular formula of $\mathrm{C}_{26} \mathrm{H}_{40} \mathrm{O}_{8}$ based on the HRESIMS data, which suggested seven indices of hydrogen deficiency (IHD). The ${ }^{1} \mathrm{H}-\mathrm{NMR}$ data showed resonances of three methyl groups $\left(\delta_{\mathrm{H}} 0.99,1.43\right.$, and 1.48) and a glucose unit $\left(\delta_{\mathrm{H}} 3.99,4.02,4.23,4.27,4.42,4.61\right.$, and 4.99). The ${ }^{13} \mathrm{C}$ NMR data, HSQC, and DEPT $\left(135^{\circ}\right)$ spectra of 3 exhibited 26 carbon resonances, including three methyls, eight methylenes, ten methines, and five $\mathrm{sp}^{3}$ carbons. The COSY and HSQC spectra established four fragments: $\mathrm{CH}-\mathrm{CH}_{2}-\mathrm{CH}, \mathrm{CH}_{2}-$ $\mathrm{CH}_{2}$, $\mathrm{CH}-\mathrm{CH}-\mathrm{CH}_{2}-\mathrm{CH}-\mathrm{CH}_{2}$, and $\mathrm{CH}-\mathrm{CH}(\mathrm{OH})-\mathrm{CH}(\mathrm{OH})-$ $\mathrm{CH}(\mathrm{OH})-\mathrm{CH}-\mathrm{CH}_{2}(\mathrm{OH})$. These structural features are consistent with a grayanane-type diterpenoid glycoside. The overall structural connectivity was established by HSQC and HMBC spectroscopic data. The HMBC correlations from $\mathrm{H}_{2}-20\left(\delta_{\mathrm{H}} 5.05\right.$ and $5.47)$ to C-1 $\left(\delta_{\mathrm{C}} 48.7\right) / \mathrm{C}-9\left(\delta_{\mathrm{C}} 54.5\right) / \mathrm{C}-10\left(\delta_{\mathrm{C}} 149.7\right)$ established an exocyclic $\Delta^{10(20)}$ double bond. The HMBC correlations from $\mathrm{H}_{3}$ $18 / \mathrm{H}_{3}-19 / \mathrm{H}_{2}-2$ to $\mathrm{C}-3\left(\delta_{\mathrm{C}} 90.1\right)$, from $\mathrm{H}-1 / \mathrm{H}_{2}-6 / \mathrm{H}_{2}-7 / \mathrm{H}_{3}-18 / \mathrm{H}_{3}-19$ to $\mathrm{C}-5\left(\delta_{\mathrm{C}} 83.7\right)$, from $\mathrm{H}-9 / \mathrm{H}_{2}-12 / \mathrm{H}-13$ to $\mathrm{C}-11\left(\delta_{\mathrm{C}} 84.5\right)$, and from 


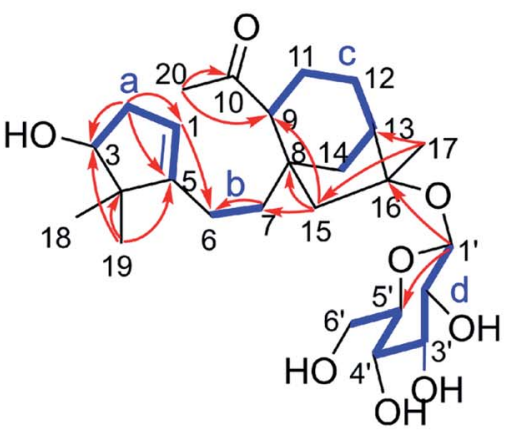

$-{ }^{1} \mathrm{H}-{ }^{1} \mathrm{H} \cos Y$

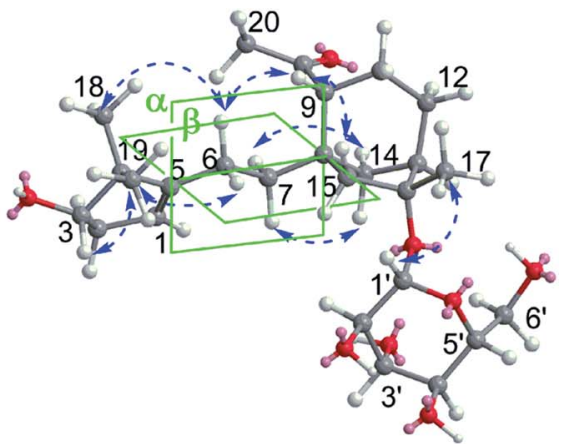

HMBC

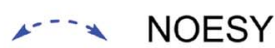

(a)

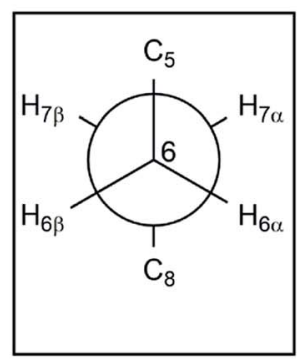

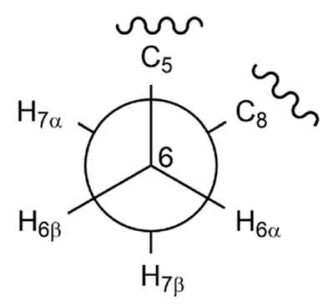

sterically hindered

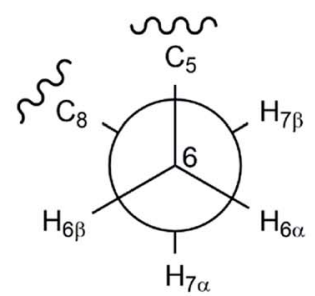

sterically hindered

(b)

Fig. 2 (a) Key ${ }^{1} \mathrm{H}-{ }^{1} \mathrm{H}$ COSY, HMBC, and NOESY correlations for 1. (b) Conformations of $\mathrm{C}-6$ and $\mathrm{C}-7$, boxes indicate conformations that agree with the measured data and are energetically favored.

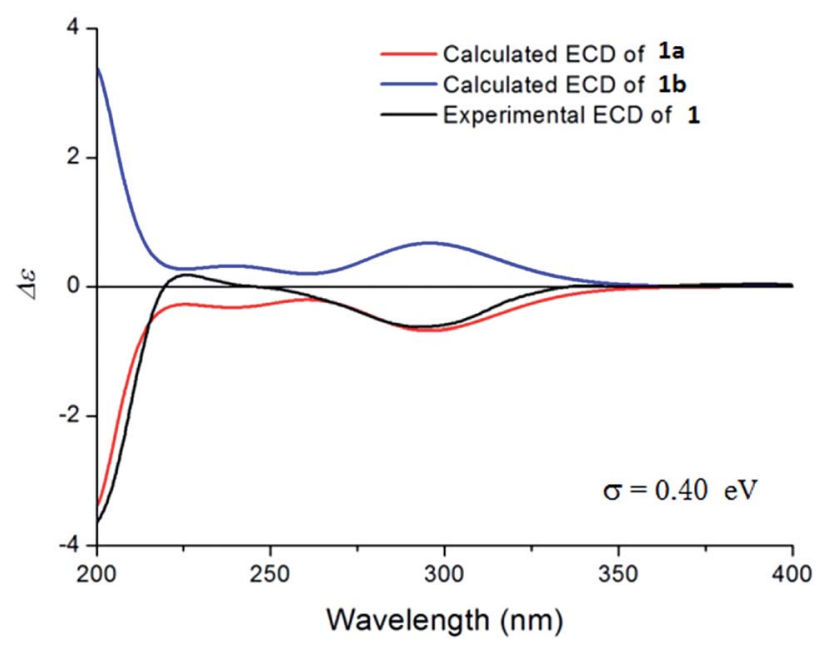

Fig. 3 The experimental CD spectrum of 1 (black) and the calculated ECD spectra of $1 \mathrm{a}$ (red) and its enantiomer $1 \mathrm{~b}$ (blue).

$\mathrm{H}_{3}-17 / \mathrm{H}_{2}-14 / \mathrm{H}_{2}-12 / \mathrm{H}-13$ to $\mathrm{C}-16\left(\delta_{\mathrm{C}} 77.4\right)$ indicated the location of four oxygenated $\mathrm{sp}^{3}$ carbons (C-3, C-5, C-11, and C-16). The skeleton (five rings including sugar part) and the exocyclic double bond accounted for six of the IHDs. The HMBC correlation from $\mathrm{H}-11$ to $\mathrm{C}-16$ suggested that $\mathrm{C}-11$ and $\mathrm{C}-16$ were connected via oxygen bridge. The glucose unit was placed at C-3 based on the HMBC correlation from $\mathrm{H}-1^{\prime}$ to $\mathrm{C}-3$. The anomeric proton at $\mathrm{H}-1^{\prime}\left(\delta_{\mathrm{H}} 4.99\right)$ showed a large coupling constant (7.8 $\mathrm{Hz}$ ), indicating that the glucose unit is found in the $\beta$-configuration. Acid hydrolysis and GC analysis of the sugar moiety of 3 confirmed that the sugar was ${ }_{\mathrm{D}}$-glucose (retention time: 29.56 min). The relative configuration of 3 was determined by the NOESY spectrum. The correlations of $\mathrm{H}-1 / \mathrm{H}_{3}-18, \mathrm{H}-3 / \mathrm{H}_{3}-18$, and $\mathrm{H}-1 / \mathrm{H}-6 \alpha$ indicated that $\mathrm{H}-1$ and $\mathrm{H}-3$ are cofacial ( $\alpha$-face) and HO-5 should be $\beta$-oriented. The correlations of $\mathrm{H}-9 / \mathrm{H}-15 \beta$ and $\mathrm{H}_{3}-17 / \mathrm{H}-12 \beta$ indicated that $\mathrm{H}-9$ and $\mathrm{CH}_{3}-17$ are cofacial ( $\beta$-face). Thus, the structure of 3 was defined as $11 \beta, 16 \alpha$-epoxy- $3 \beta-\left[\left(\beta-\right.\right.$ D- $^{-}$ glucopyranosyl)oxy]-5 $\beta$-hydroxygrayanan-10(20)-ene.

Compound 4 (micranthanoside IV) was obtained as white powder. Its molecular formula was defined as $\mathrm{C}_{26} \mathrm{H}_{38} \mathrm{O}_{7}$ based on HRESIMS $\left(\mathrm{m} / \mathrm{z} 485.2492[\mathrm{M}+\mathrm{Na}]^{+}\right.$, calcd 485.2510), which indicated an IHD of eight. Preliminary ${ }^{1} \mathrm{H}$ and ${ }^{13} \mathrm{C}$ analyses of 4 indicated the presence of a common grayanane skeleton. The NMR spectroscopic data of $\mathbf{4}$ were comparable to those of pierisformoside C. ${ }^{\mathbf{1 6}}$ The only difference was the location of the double bond. The HMBC correlations from $\mathrm{H}_{3}-20 / \mathrm{H}_{2}-11$ to $\mathrm{C}-9$ $\left(\delta_{\mathrm{C}} 142.6\right) / \mathrm{C}-10\left(\delta_{\mathrm{C}} 124.3\right)$ located the double bond at $\Delta^{9,10}$ instead of $\Delta^{10,20}$. The glucose unit was placed at C-3 based on the $\mathrm{HMBC}$ correlation from $\mathrm{H}-\mathbf{1}^{\prime}$ to $\mathrm{C}-3$. The anomeric proton at $\mathrm{H}-1^{\prime}\left(\delta_{\mathrm{H}} 5.03\right)$ showed a large coupling constant $(7.8 \mathrm{~Hz})$, indicating that the glucose unit is in $\beta$-configuration. Acid hydrolysis gave a D-glucose, which was identified by GC analysis (retention time: $29.49 \mathrm{~min}$ ). In the NOESY spectrum, the correlations of $\mathrm{H}-3 / \mathrm{H}_{3}-18$ indicated that $\mathrm{H}-3$ is $\alpha$-oriented. Thus, 
Table $2{ }^{1} \mathrm{H}$ NMR spectroscopic data for compounds $8-11$ in pyridine- $d_{5}(\delta$ in ppm, $J$ in $\mathrm{Hz}$ )

\begin{tabular}{|c|c|c|c|c|}
\hline No & $8^{b}$ & $\mathbf{9}^{a}$ & $10^{a}$ & $11^{a}$ \\
\hline 1 & $2.78, \mathrm{dd}(11.9,7.4)$ & $3.14, \mathrm{~m}$ & $3.26, \mathrm{t}(9.3)$ & $3.18, \mathrm{t}(9.4)$ \\
\hline 2 & $1.54, \mathrm{~m}$ & $2.13, \mathrm{~m}$ & 2.16, dd $(14.0,9.3)$ & $2.23, \mathrm{~m}$ \\
\hline \multirow[t]{2}{*}{3} & $1.47, \mathrm{~m}$ & $4.01, \mathrm{~m}$ & 4.11 , brs & $3.94, \mathrm{~d}(5.0)$ \\
\hline & $2.39, \mathrm{~m}$ & - & - & - \\
\hline 4 & - & - & - & - \\
\hline & $1.72, \mathrm{~m}$ & $1.67, \mathrm{~m}$ & $1.53, \mathrm{~m}$ & - \\
\hline \multirow[t]{2}{*}{7} & $1.83, \mathrm{~m}$ & $1.68, \mathrm{~m}$ & $1.72, \mathrm{~m}$ & $2.02, \mathrm{~d}(13.7)$ \\
\hline & $1.89, \mathrm{~m}$ & $1.73, \mathrm{~m}$ & $2.67, \mathrm{~m}$ & 2.76, dd $(14.4,9.8)$ \\
\hline 8 & - & - & - & - \\
\hline 9 & $2.13, \mathrm{~m}$ & $3.11, \mathrm{~m}$ & $2.29, \mathrm{~m}$ & $2.80, \mathrm{~m}$ \\
\hline 10 & - & - & - & - \\
\hline 13 & $2.44, \mathrm{~m}$ & 2.51, brs & $2.62, \mathrm{~m}$ & 2.22 , brs \\
\hline \multirow[t]{2}{*}{14} & $1.64, \mathrm{~m}$ & $1.50, \mathrm{~m}$ & $1.88, \mathrm{~d}(11.1)$ & $1.92, \mathrm{~d}(11.1)$ \\
\hline & $2.20, \mathrm{~m}$ & $1.70, \mathrm{~m}$ & $2.22, \mathrm{~m}$ & 2.36, dd $(11.0,4.1)$ \\
\hline \multirow[t]{2}{*}{15} & $1.79, \mathrm{~d}(13.4)$ & $1.88, \mathrm{~d}(14.0)$ & $1.69, \mathrm{~d}(13.9)$ & $2.11, \mathrm{~d}(13.7)$ \\
\hline & $2.33, \mathrm{~d}(14.1)$ & $2.33, \mathrm{~d}(14.3)$ & $2.26, \mathrm{~d}(15.0)$ & $2.29, \mathrm{~d}(14.0)$ \\
\hline 16 & - & - & - & - \\
\hline 17 & $1.62, \mathrm{~s}$ & $1.62, \mathrm{~s}$ & $1.60, \mathrm{~s}$ & $1.55, \mathrm{~s}$ \\
\hline \multirow[t]{2}{*}{18} & $3.83, \mathrm{~m}$ & $0.80, \mathrm{~s}$ & $0.80, \mathrm{~s}$ & $1.34, \mathrm{~s}$ \\
\hline & $3.99, \mathrm{~m}$ & - & - & - \\
\hline 19 & $1.05, \mathrm{~s}$ & $1.29, \mathrm{~s}$ & $1.28, \mathrm{~s}$ & $1.69, \mathrm{~s}$ \\
\hline \multirow[t]{2}{*}{20} & $5.22, \mathrm{~s}$ & $5.10, \mathrm{~s}$ & $5.17, \mathrm{~s}$ & $5.19, \mathrm{~s}$ \\
\hline & $5.31, \mathrm{~s}$ & $5.14, \mathrm{~s}$ & $5.19, \mathrm{~s}$ & $5.22, \mathrm{~s}$ \\
\hline
\end{tabular}

the structure of $\mathbf{4}$ was defined as $3 \beta-[(\beta-D-$ glucopyranosyl)oxy]16 $\alpha$-hydroxygrayanan-1(5),6(7),9(10)-triene.

HRESIMS analysis of compound 5 (micranthanoside $\mathrm{V}$ ) indicated a molecular formula of $\mathrm{C}_{26} \mathrm{H}_{42} \mathrm{O}_{9}$. Spectroscopic data for 5 resembled those of pieroside $\mathrm{C}$, which differs from 5 with regard to the position of the glucose unit. ${ }^{17}$ The HMBC correlations from $\mathrm{H}-1^{\prime}$ to $\mathrm{C}-16$ placed the glucose unit at $\mathrm{C}-16$ instead of $\mathrm{C}-3$ as in pieroside $\mathrm{C}$. A large coupling constant $(7.8 \mathrm{~Hz})$ of the anomeric proton indicated the $\beta$-configuration of the glucose. In the NOESY spectrum, the correlations of $\mathrm{H}_{3}-18 / \mathrm{H}-1, \mathrm{H}_{3}-18 / \mathrm{H}-$ 3 , and $\mathrm{H}_{3}-18 / \mathrm{H}-6$ indicated that $\mathrm{H}-1, \mathrm{H}-3$, and $\mathrm{H}-6$ are $\alpha-$ oriented, and the correlations of $\mathrm{H}_{3}-17 / \mathrm{H}-11 \beta$ indicated that $\mathrm{CH}_{3}-17$ is $\beta$-oriented. Acid hydrolysis and GC analysis of the sugar moiety of $\mathbf{5}$ confirmed that the sugar was D-glucose (retention time: $29.60 \mathrm{~min}$ ). Thus, the structure of $\mathbf{5}$ was defined as $16 \alpha-[(\beta$-D-glucopyranosyl)oxy]-3 $\beta, 5 \beta, 6 \beta$-trihydroxygrayanan9(10)-ene.

Compound 6 (micranthanoside VI) was found by mass spectrometry to have a molecular formula of $\mathrm{C}_{26} \mathrm{H}_{40} \mathrm{O}_{7}$. The ${ }^{1} \mathrm{H}$ and ${ }^{13} \mathrm{C}$ NMR spectroscopic data indicated that 6 has a grayanane skeleton. Its ${ }^{13} \mathrm{C}$ NMR spectrum exhibited the typical resonances of two double bonds and an anomeric carbon at $\delta_{\mathrm{C}}$ 107.2, 152.4, 118.3, 156.4, and 99.8. Further HSQC and HMBC experiments allowed full assignment of the ${ }^{1} \mathrm{H}$ and ${ }^{13} \mathrm{C}$ NMR spectra of 6 . The location of the two double bonds $\left(\Delta^{5,6}, \Delta^{10,20}\right)$ was determined via HMBC correlations from $\mathrm{H}-1$ to $\mathrm{C}-5 / \mathrm{C}-10$, from $\mathrm{H}_{2}-20$ to $\mathrm{C}-1 / \mathrm{C}-9 / \mathrm{C}-10$, and from $\mathrm{H}_{2}-7$ to $\mathrm{C}-5 / \mathrm{C}-6$. The glucose unit was placed at $\mathrm{C}-16$, which was supported by the HMBC correlation from $\mathrm{H}-1^{\prime}$ to $\mathrm{C}-16$. Acid hydrolysis and GC analysis of the sugar moiety of 6 confirmed that the sugar was $\mathrm{D}^{-}$ glucose (retention time: $29.56 \mathrm{~min}$ ). The relative configuration of 6 was established by the NOESY experiment. The correlations of $\mathrm{H}-1 / \mathrm{H}_{3}-18, \mathrm{H}_{3}-18 / \mathrm{H}-3$, and $\mathrm{H}-1 / \mathrm{H}-9$ indicated that $\mathrm{H}-1, \mathrm{H}-3$, and $\mathrm{H}-9$ are $\alpha$-oriented. Thus, the structure of 6 was defined as 9-epi-16 $\alpha$-[( $\beta$-D-glucopyranosyl)oxy]-3 $\beta$-hydroxygrayanan5(6),10(20)-diene.

Compound 7 (micranthanoside VII) was determined to have the formula $\mathrm{C}_{26} \mathrm{H}_{40} \mathrm{O}_{7}$. The planar structure of 7 was found to be 
Table $3{ }^{1} \mathrm{H}$ NMR spectroscopic data for compounds $12-15$ in pyridine $-d_{5}(\delta$ in ppm, $J$ in $\mathrm{Hz})$

\begin{tabular}{|c|c|c|c|c|}
\hline No & $12^{a}$ & $13^{a}$ & $14^{a}$ & $15^{a}$ \\
\hline \multirow[t]{2}{*}{1} & $1.72, \mathrm{~m}$ & $1.46, \mathrm{~m}$ & $1.46, \mathrm{~m}$ & $1.66, \mathrm{t}(13.7)$ \\
\hline & $1.97, \mathrm{~m}$ & $2.07, \mathrm{~m}$ & $1.96, \mathrm{~m}$ & \\
\hline \multirow[t]{2}{*}{2} & $1.42, \mathrm{~m}$ & 1.84, dd $(13.9,2.4)$ & $1.43, \mathrm{~m}$ & $2.18, \mathrm{~m}$ \\
\hline & $1.72, \mathrm{~m}$ & $2.14, \mathrm{~m}$ & $1.82, \mathrm{~m}$ & $2.56, \mathrm{~m}$ \\
\hline \multirow[t]{2}{*}{3} & $4.68, \mathrm{dd}(11.4,1.9)$ & $3.65, \mathrm{~d}(2.5)$ & $0.92, \mathrm{~d}(12.7)$ & $3.99, \mathrm{~m}$ \\
\hline & - & - & $2.68, \operatorname{td}(13.3,4.1)$ & - \\
\hline 4 & - & - & - & - \\
\hline 5 & - & - & - & - \\
\hline \multirow[t]{2}{*}{6} & 4.09, brs & - & - & $2.53, \mathrm{~m}$ \\
\hline & - & - & - & - \\
\hline \multirow[t]{2}{*}{7} & $2.07, \mathrm{~m}$ & $2.22, \mathrm{~d}(11.6)$ & $2.21, \mathrm{~d}(11.8)$ & $1.78, \mathrm{~m}$ \\
\hline & $2.45, \mathrm{t}(12.1)$ & 3.96, d (11.4) & $4.07, \mathrm{~d}(11.9)$ & $1.78, \mathrm{~m}$ \\
\hline 8 & - & - & - & - \\
\hline 9 & $2.09, \mathrm{~m}$ & $2.59, \mathrm{~d}(8.7)$ & $2.57, \mathrm{~d}(8.5)$ & $1.95, \mathrm{~m}$ \\
\hline 10 & - & - & - & - \\
\hline \multirow[t]{2}{*}{11} & $1.42, \mathrm{~m}$ & $1.46, \mathrm{~m}$ & $1.57, \mathrm{~m}$ & $1.59, \mathrm{~m}$ \\
\hline & $1.60, \mathrm{~d}(13.1)$ & $1.64, \mathrm{~m}$ & $1.62, \mathrm{~m}$ & $1.94, \mathrm{~m}$ \\
\hline \multirow[t]{2}{*}{12} & $1.51, \mathrm{~m}$ & $1.53, \mathrm{~m}$ & $1.48, \mathrm{~m}$ & $1.52, \mathrm{~m}$ \\
\hline & $1.60, \mathrm{~m}$ & $1.57, \mathrm{~m}$ & $1.56, \mathrm{~m}$ & $1.59, \mathrm{~m}$ \\
\hline 13 & 2.54, brs & 2.51, brs & 2.52, brs & $2.12, \mathrm{~d}(2.9)$ \\
\hline \multirow[t]{2}{*}{14} & $1.96, \mathrm{~m}$ & $1.92, \mathrm{~d}(11.4)$ & $1.91, \mathrm{~d}(11.4)$ & $1.78, \mathrm{t}(12.8)$ \\
\hline & $2.29, \mathrm{~m}$ & $2.30, \mathrm{dd}(11.3,4.0)$ & $2.28, \mathrm{~m}$ & $2.02, \mathrm{~m}$ \\
\hline \multirow[t]{2}{*}{15} & $1.60, \mathrm{~d}(13.1)$ & $1.74, \mathrm{~d}(14.1)$ & $1.75, \mathrm{~d}(14.1)$ & $1.86, \mathrm{~d}(13.9)$ \\
\hline & $2.39, \mathrm{~d}(14.0)$ & $2.35, \mathrm{~d}(14.1)$ & $2.31, \mathrm{~d}(14.3)$ & $2.04, \mathrm{~m}$ \\
\hline 16 & - & - & - & - \\
\hline \multirow[t]{2}{*}{17} & $1.66, \mathrm{~s}$ & $1.62, \mathrm{~s}$ & $1.61, \mathrm{~s}$ & $1.54, \mathrm{~s}$ \\
\hline & & - & - & - \\
\hline \multirow[t]{2}{*}{18} & $4.83, \mathrm{~s}$ & $1.52, \mathrm{~s}$ & $1.31, \mathrm{~s}$ & $1.20, \mathrm{~s}$ \\
\hline & $5.10, \mathrm{~s}$ & & & \\
\hline \multirow[t]{2}{*}{19} & $1.74, \mathrm{~s}$ & $1.50, \mathrm{~s}$ & $3.4, \mathrm{~d}(8.3)$ & $1.51, \mathrm{~s}$ \\
\hline & & & 4.56, dd $(10.7,4.7)$ & \\
\hline \multirow[t]{2}{*}{20} & $1.23, \mathrm{~s}$ & $1.12, \mathrm{~s}$ & $1.11, \mathrm{~s}$ & $4.89, \mathrm{~s}$ \\
\hline & - & - & - & $5.06, \mathrm{~s}$ \\
\hline $1^{\prime}$ & $4.99, \mathrm{~d}(7.8)$ & $4.96, \mathrm{~d}(7.8)$ & $4.95, \mathrm{~d}(8.1)$ & $5.02, \mathrm{~d}(7.7)$ \\
\hline $2^{\prime}$ & 3.98 , brs & $3.97, \mathrm{~m}$ & 3.96, brs & $4.08, \mathrm{t}(8.2)$ \\
\hline $3^{\prime}$ & $4.29, \mathrm{~m}$ & $4.25, \mathrm{~m}$ & $4.25, \mathrm{~m}$ & $4.31, \mathrm{~m}$ \\
\hline $4^{\prime}$ & $4.29, \mathrm{~m}$ & $4.27, \mathrm{~m}$ & $4.27, \mathrm{~m}$ & $4.28, \mathrm{~m}$ \\
\hline $5^{\prime}$ & 3.93 , brs & $3.91, \mathrm{brs}$ & 3.91, brs & $4.02, \mathrm{~m}$ \\
\hline \multirow[t]{2}{*}{$6^{\prime}$} & $4.40, \mathrm{~m}$ & 4.38, dd $(11.6,5.1)$ & $4.39, \mathrm{~d}(12.4)$ & $4.41, \mathrm{dd}(11.6,5.4)$ \\
\hline & $4.52, \mathrm{~d}(10.1)$ & 4.51, dd $(11.6,2.3)$ & $4.51, \mathrm{~d}(11.4)$ & 4.59, dd $(11.6,2.4)$ \\
\hline
\end{tabular}

identical to that of 6 except for the location of the sugar moiety. The HMBC correlations from $\mathrm{H}-1^{\prime}$ to $\mathrm{C}-3$ placed the sugar moiety at C-3. The correlations of $\mathrm{H}_{3}-18 / \mathrm{H}-3, \mathrm{H}-3 / \mathrm{H}-1$, and $\mathrm{H}-1 /$ $\mathrm{H}-9$ in the NOESY spectrum indicated that $\mathrm{H}-1, \mathrm{H}-3$, and $\mathrm{H}-9$ are $\alpha$-oriented. Thus, the structure of 7 was defined as 9 -epi-3 $\beta-[(\beta-\mathrm{D}-$ glucopyranosyl)oxy]-16 $\alpha$-hydroxygrayanan-5(6),10(20)-diene.

The formula of compound 8 (micranthanoside VIII) was identified as $\mathrm{C}_{26} \mathrm{H}_{42} \mathrm{O}_{8}$ by HRESIMS, indicating an IHD of six. The ${ }^{1} \mathrm{H}$ (Table 2) and ${ }^{13} \mathrm{C}$ NMR data of 8 were similar to those of micranthanoside $\mathrm{E}^{\mathbf{1 3}}$ except for the differences associated with the locations of the hydroxy groups. In micranthanoside $\mathrm{E}$, the hydroxy groups were placed at C-3 and C-6. However, the hydroxy group was placed at C-18 in 8 indicated by the HMBC correlations from $\mathrm{H}_{3}-19 / \mathrm{H}_{2}-3$ to $\mathrm{C}-18$. The NOESY correlations of $\mathrm{H}-1 / \mathrm{H}_{3}-19, \mathrm{H}-1 / \mathrm{H}-9, \mathrm{H}-9 / \mathrm{H}-15 \beta$, and $\mathrm{H}_{3}-17 / \mathrm{H}-12 \beta$ suggested that $\mathrm{H}-1, \mathrm{H}-9, \mathrm{CH}_{3}-17$ and $\mathrm{CH}_{3}-19$ are $\beta$-oriented. Thus, the structure of 8 was defined as 1-epi-16 $\alpha$-[( $\beta$-D-glucopyranosyl) oxy]-5 $\beta$-hydroxygrayanan-10(20)-ene-18-ol.

Compound 9 (micranthanoside IX) exhibited a molecular formula of $\mathrm{C}_{26} \mathrm{H}_{42} \mathrm{O}_{8}$ based on the HRESIMS results. The ${ }^{1} \mathrm{H}$ and ${ }^{13} \mathrm{C}$ NMR spectroscopic data suggested that 9 has a grayanane skeleton similar to that of a known analogue, 6-deoxygrayanotoxin XVII, ${ }^{\mathbf{1 8}}$ and an extra sugar moiety was the only difference. The glucose unit was placed at C-16 based on the HMBC correlation from $\mathrm{H}-1^{\prime}$ to $\mathrm{C}-16$. The NOESY correlations of $\mathrm{H}-1 / \mathrm{H}_{3}-18, \mathrm{H}_{3}-17 / \mathrm{H}-12 \beta$, and $\mathrm{H}-9 / \mathrm{H}_{3}-17$ indicated that $\mathrm{H}-1$ is $\alpha-$ oriented and $\mathrm{H}-9$ and $\mathrm{CH}_{3}-17$ are $\beta$-oriented. Acid hydrolysis and GC analysis of the sugar moiety of 9 confirmed that the sugar was D-glucose (retention time: $29.53 \mathrm{~min}$ ). Thus, the structure of 9 was defined as $16 \alpha-[(\beta$-D-glucopyranosyl)oxy]-

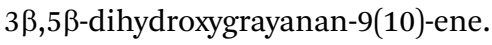




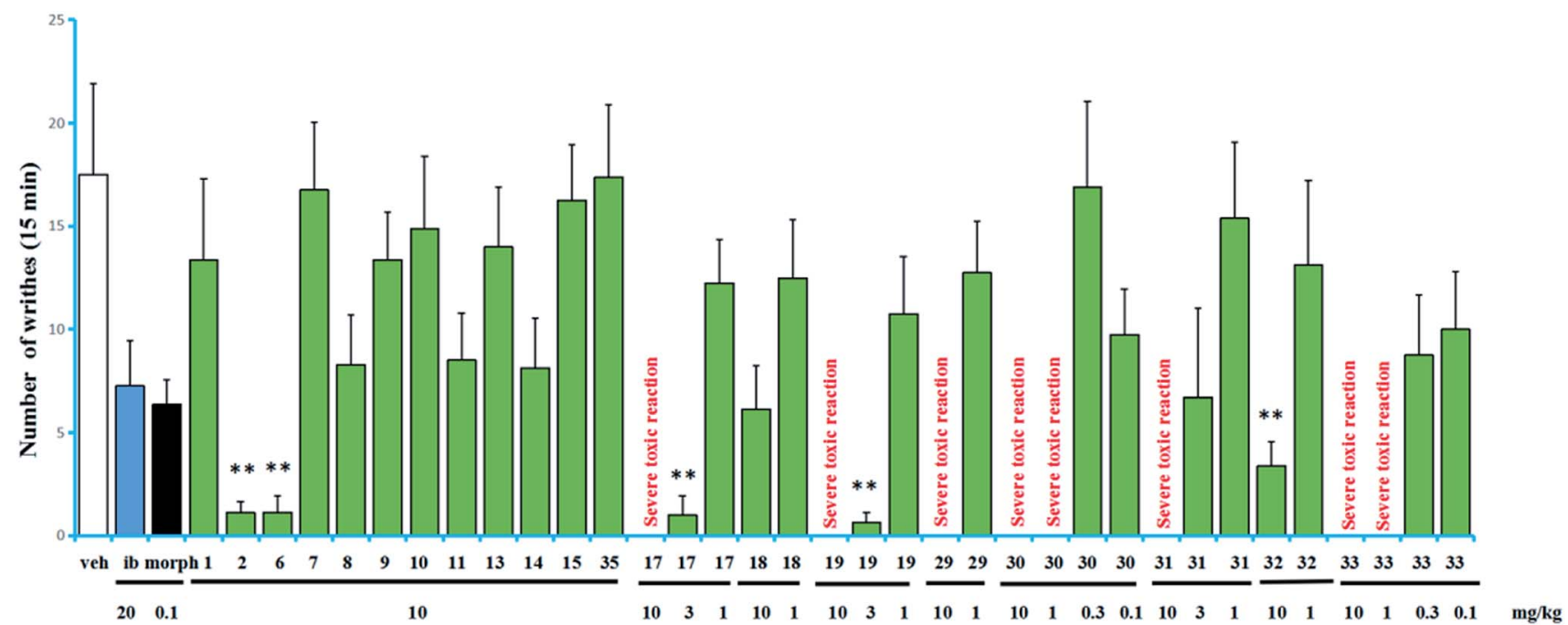

Fig. 4 Antinociceptive activities of partial diterpenoids isolated from $R$. micranthum. Data represent the mean $\pm \mathrm{SEM}$. *p $<0.05, * * p<0.01, v S$. vehicle (veh). Control drugs: ibuprofen (ib) and morphine (morph).

The molecular formula of compound $\mathbf{1 0}$ (micranthanoside X) was determined as $\mathrm{C}_{26} \mathrm{H}_{42} \mathrm{O}_{8}$, implying an IHD of six. The HSQC and HMBC spectra indicated that the planar structure of 10 was the same as that of 9. The NOESY correlations of $\mathrm{H}-1 / \mathrm{H}-$ 9, $\mathrm{H}-1 / \mathrm{HO}-5, \mathrm{H}_{3}-19 / \mathrm{HO}-5$, and $\mathrm{H}_{3}-17 / \mathrm{H}-12 \beta$ in 10 indicated that $\mathrm{H}-1$ is $\beta$-oriented, which is the only difference between the two compounds. Acid hydrolysis and GC analysis of the sugar moiety of $\mathbf{1 0}$ confirmed that the sugar was D-glucose (retention time: $29.55 \mathrm{~min})$. Thus, the structure of 10 was defined as 1-epi$16 \alpha$-[( $\beta$-D-glucopyranosyl)oxy]-3 $\beta, 5 \beta$-dihydroxygrayanan-9(10)ene.

The molecular formula of compound $\mathbf{1 1}$ (micranthanoside XI) was determined as $\mathrm{C}_{26} \mathrm{H}_{42} \mathrm{O}_{9}$, implying an IHD of six. The ${ }^{1} \mathrm{H}$ and ${ }^{13} \mathrm{C}$ NMR data of $\mathbf{1 1}$ were similar to that of grayanotoxin-XVIII (17) except for signal of an additional sugar moiety. ${ }^{19}$ The glucose unit was placed at C-6 as suggested by the HMBC correlations from $\mathrm{H}-1^{\prime}$ to $\mathrm{C}-6$. The NOESY correlations of $\mathrm{H}-3 / \mathrm{H}_{3}-18, \mathrm{H}-1 / \mathrm{H}-6, \mathrm{H}-6 / \mathrm{H}_{3}-18, \mathrm{H}-1 /$
$\mathrm{H}_{3}-18, \mathrm{H}_{3}-17 / \mathrm{H}-9$, and $\mathrm{H}-9 / \mathrm{H}-15 \beta$ indicated that $\mathrm{H}-1, \mathrm{H}-3$, and $\mathrm{H}-6$ are $\alpha$-oriented and $\mathrm{H}-9$ and $\mathrm{H}_{3}-17$ are $\beta$-oriented. Thus, the structure of $\mathbf{1 1}$ was defined as $6 \beta-[(\beta$-D-glucopyranosyl) oxy]-3 $\beta, 5 \beta, 16 \alpha$-trihydroxygrayanan-9(10)-ene.

Compound 12 was obtained as white powder and determined to have the molecular formula $\mathrm{C}_{26} \mathrm{H}_{42} \mathrm{O}_{9}$ by HRESIMS. The ${ }^{1} \mathrm{H}$ (Table 3) and ${ }^{13} \mathrm{C}$ NMR spectroscopic data suggested that 12 has a 4,5-seco-ent-kaurane skeleton similar to known analogues. ${ }^{14}$ The ${ }^{1} \mathrm{H},{ }^{13} \mathrm{C}$, and HSQC NMR data for 12 indicated the presence of a sugar unit $\left(\delta_{\mathrm{C}} 63.4,72.3,75.8,78.3\right.$, 79.4, and 99.9) and two olefinic carbons $\left(\delta_{\mathrm{C}} 110.5\right.$ and 148.0). The overall structural connectivity was established by HSQC and $\mathrm{HMBC}$ spectroscopic data. The HMBC correlations from HO-5 to C-5/C-10 and from $\mathrm{H}-6$ to $\mathrm{C}-7$ placed two hydroxy groups at C-5 and C-6. The sugar unit was placed at C-16 suggested by HMBC correlations of $\mathrm{H}-1^{\prime}$ to $\mathrm{C}-16$. An oxygen bridge should be present between $\mathrm{C}-3$ and $\mathrm{C}-5$, which was supported by the HMBC correlation from $\mathrm{H}-3$ to $\mathrm{C}-5$. The

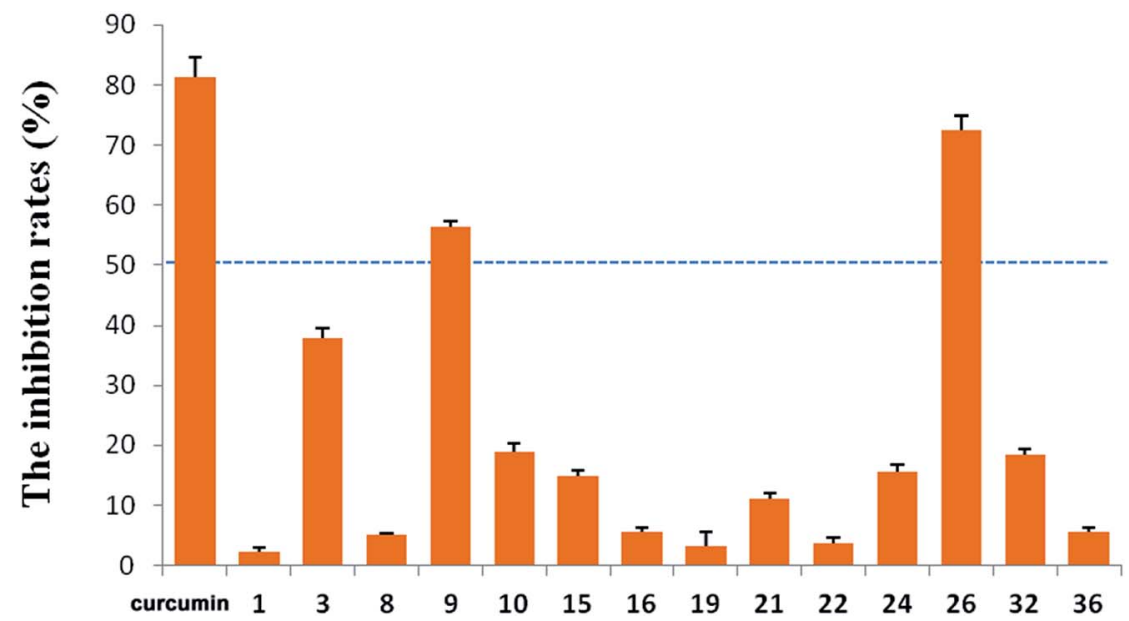

Fig. 5 Inhibitory effects of LPS-induced NO production in BV2 cells. 
Table $4{ }^{13}$ C NMR spectroscopic data for compounds $1-16$ in pyridine- $d_{5}(\delta$ in ppm)

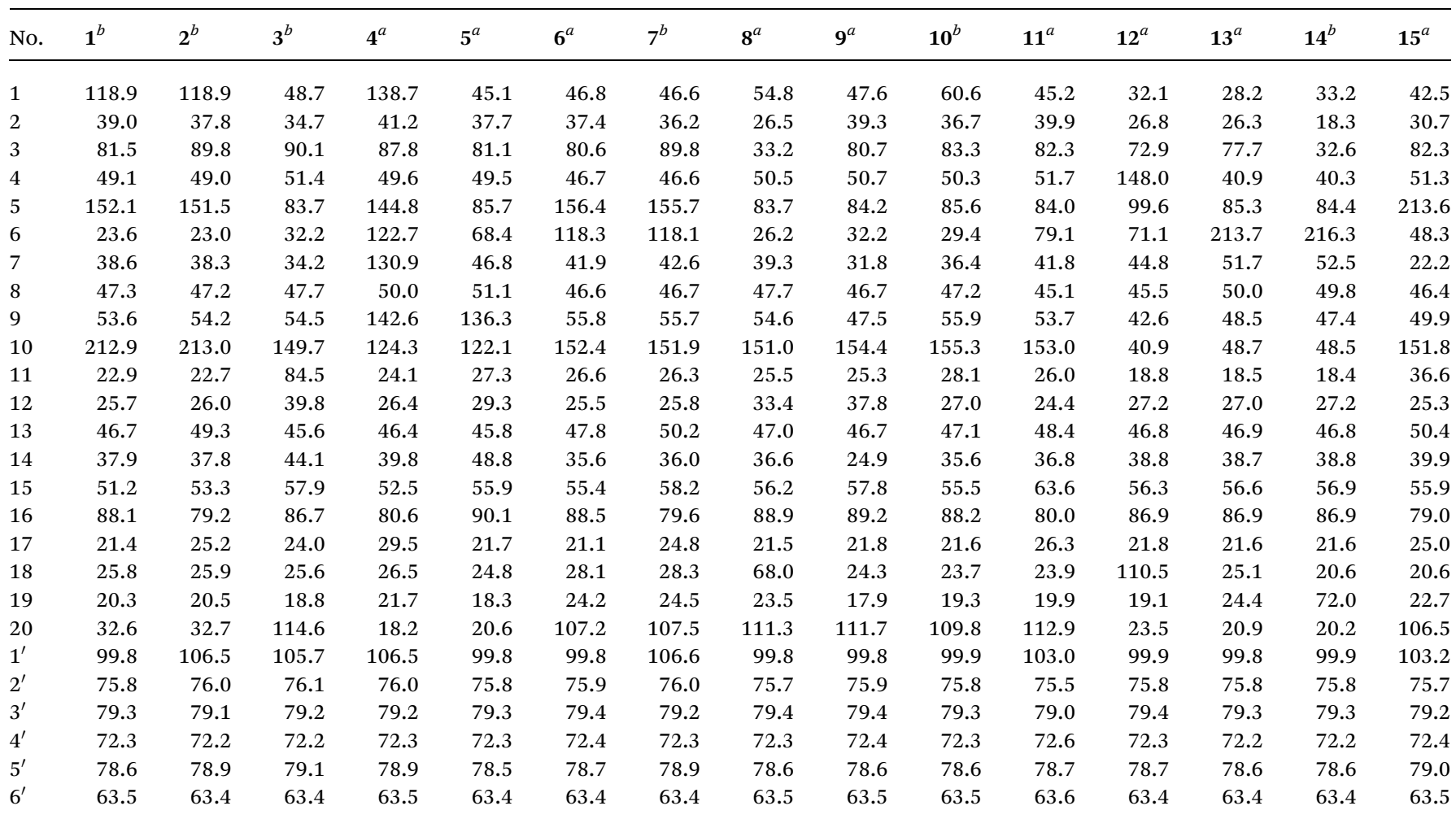

${ }^{a}$ Recorded at $125 \mathrm{MHz}{ }^{b}$ Recorded at $150 \mathrm{MHz}$.

NOESY correlations of $\mathrm{H}-3 / \mathrm{H}-1 \beta, \mathrm{H}-1 \beta / \mathrm{H}-9, \mathrm{H}-9 / \mathrm{H}-12 \beta$, and $\mathrm{H}_{3}-20 / \mathrm{H}-6$ suggested that $\mathrm{H}-3$ and $\mathrm{H}-9$ are $\beta$-oriented and $\mathrm{H}-6$ is $\alpha$-oriented. Thus, the structure of $\mathbf{1 2}$ was named as micranthanoside XII. Micranthanoside XII (12) represent the first example of 3,5-epoxy-4,5-seco-ent-kaurane diterpenoid.

Compound 13 (micranthanoside XIII) has a molecular formula of $\mathrm{C}_{26} \mathrm{H}_{42} \mathrm{O}_{9}$. Preliminary analyses of the NMR data indicated the presence of an ent-kaurane skeleton. The NMR spectra indicated the presence of two hydroxy groups, a carbonyl group, and a sugar moiety. The two hydroxy groups were placed at C- 3 and C-5 on the basis of the correlations from HO-3 to C-2/C-3/C-4 and from HO-5 to C-4/C-5/C-6, respectively. The HMBC correlation from $\mathrm{H}-1^{\prime}$ to $\mathrm{C}-16$ indicated that the sugar moiety was located at C-16. The HMBC correlations from $\mathrm{H}_{2}-7$ to $\mathrm{C}-6$ placed the carbonyl group at C-6. In the NOESY spectrum of 13, correlations of $\mathrm{H}-3 / \mathrm{HO}-5, \mathrm{H}-3 / \mathrm{H}_{3}-19, \mathrm{H}_{3}-18 / \mathrm{HO}-$ $3, \mathrm{H}_{3}-20 / \mathrm{H}-14 \alpha$, and $\mathrm{H}-9 / \mathrm{H}-15 \beta$ indicated that $\mathrm{H}-3, \mathrm{HO}-5$, and $\mathrm{H}-$ 9 are $\beta$-oriented and $\mathrm{CH}_{3}-20$ is $\alpha$-oriented. Acid hydrolysis and GC analysis of $\mathbf{1 3}$ confirmed that the sugar moiety was D-glucose (retention time: $29.54 \mathrm{~min}$ ). Thus, the structure of 13 was defined as $16 \alpha$-[( $\beta$-D-glucopyranosyl)oxy]-3 $\alpha, 5 \beta$-dihydroxy-entkaur-6-one.

Compound 14 (micranthanoside XIV) has a molecular formula of $\mathrm{C}_{26} \mathrm{H}_{42} \mathrm{O}_{9}$. The ${ }^{1} \mathrm{H}$ and ${ }^{13} \mathrm{C}$ NMR data of 14 were similar to those of 13. The HMBC correlations from $\mathrm{H}_{3}-18$ to C-19 indicated that the hydroxy group was at C-19 in 14 instead of at $\mathrm{C}-3$ as in 13. In the NOESY spectrum, the correlations of $\mathrm{H}_{3}-20 / \mathrm{H}_{3}-18, \mathrm{H}_{3}-20 / \mathrm{H}-14 \alpha$, and $\mathrm{H}-9 / \mathrm{H}-15 \beta$ indicated that $\mathrm{H}-9$ is $\beta$-oriented and $\mathrm{CH}_{3}-20$ is $\alpha$-oriented. Acid hydrolysis and GC analysis of $\mathbf{1 4}$ confirmed that the sugar moiety was D-glucose (retention time: $29.50 \mathrm{~min}$ ). Thus, the structure of 14 was defined as $16 \alpha$-[( $\beta$-D-glucopyranosyl) oxy]-5 $\beta$-hydroxy-ent-kaur-6-one-19-ol.

Compound 15 (micranthanoside XV) has a molecular formula of $\mathrm{C}_{26} \mathrm{H}_{40} \mathrm{O}_{8}$. Preliminary ${ }^{1} \mathrm{H}$ and ${ }^{13} \mathrm{C}$ analyses of 15 indicated the presence of a leucothane skeleton. The ${ }^{13} \mathrm{C}$ NMR spectrum displayed resonances of a carbonyl group, a sugar moiety and a double bond. The sugar moiety and the carbonyl group were placed at $\mathrm{C}-3$ and $\mathrm{C}-5$ based on the HMBC correlations from $\mathrm{H}-\mathbf{1}^{\prime}$ to $\mathrm{C}-3$ and from $\mathrm{H}_{3}-18 / \mathrm{H}_{3}-19 / \mathrm{H}-$ 6 to $\mathrm{C}-5$, respectively. The HMBC correlations from $\mathrm{H}_{2}-20$ to C-1/C-9/C-10 suggested that the exocyclic double bond is $\Delta^{10(20)}$. The NOESY correlations of $\mathrm{H}-3 / \mathrm{H}-1, \mathrm{H}-3 / \mathrm{H}_{3}-19, \mathrm{H}-6 /$ $\mathrm{H}_{3}-18$, and $\mathrm{H}-9 / \mathrm{H}-15 \beta$ indicated that $\mathrm{H}-1, \mathrm{H}-3$, and $\mathrm{H}-9$ are $\beta$ oriented and $\mathrm{H}-6$ is $\alpha$-oriented. Acid hydrolysis and GC analysis confirmed that the sugar moiety was D-glucose (retention time: $29.64 \mathrm{~min}$ ). Thus, the structure of 15 was defined as $3 \alpha$-[( $\beta$-D-glucopyranosyl)oxy]-16 $\alpha$-hydroxyleucoth10(20)-en-5-one.

The known compounds micranthanoside $\mathrm{F}(\mathbf{1 6}),{ }^{\mathbf{1 3}}$ grayanotoxin XVIII (17), ${ }^{19}$ pierisformosin A (18), ${ }^{20}$ 6-deoxy-1-epigrayanotoxin XVII (19), ${ }^{18}$ grayanotoxin IV (20), ${ }^{21}$ grayanoside C (21), ${ }^{22}$ grayanotoxin II (22) ${ }^{23}$ grayanoside B (23), ${ }^{19}$ micranthanosides $\mathrm{C}(\mathbf{2 4})$ and $\mathrm{A}(\mathbf{2 5}),{ }^{\mathbf{1 3}}$ rhodomicranoside $\mathrm{F}(\mathbf{2 6}),{ }^{\mathbf{1 4}}$ grayanotoxins I (27), ${ }^{21}$ III (28), ${ }^{24}$ VII (29), ${ }^{25}$ IX (30), ${ }^{26}$ and VIII $(31),{ }^{26}$ 19-sophorosyl kaurenoate $(32),{ }^{27}$ kalmanol (33), ${ }^{28}$ 
rhodomicranoside A (34), ${ }^{14}$ pieroside $\mathrm{B}(35),{ }^{29}$ and pierisformoside $\mathrm{F}(\mathbf{3 6})^{16}$ were determined by comparison of their experimental NMR data with those reported in the literature.

The acetic acid-induced writhing test is usually used as a sensitive model for measuring acute pain.${ }^{6-9}$ Compounds 12, 6-11, 13-15, 17-19, 29-33, and 35 were evaluated in the test for their antinociceptive activity based on the inhibition rates of writhes. In this test, intraperitoneal (IP) administration was used for all of the compounds. The obtained data are summarized in Fig. 4. Compounds 17 and 19 showed higher inhibitory activities than the other tested compounds, inhibited $94.3 \%$ and $96.4 \%$ of the writhes, respectively, when administered at a dose of $3 \mathrm{mg} \mathrm{kg}{ }^{-1}$. However, they showed severe toxic reactions when administered at a dose of $10 \mathrm{mg}$ $\mathrm{kg}^{-1}$. Compounds 2, 6 and 32 showed significant antinociceptive activity at a dose of $10 \mathrm{mg} \mathrm{kg}^{-1}$. In contrast, in the same assay, ibuprofen inhibited $58.6 \%$ of the writhes when administered at a dose of $20 \mathrm{mg} \mathrm{kg}{ }^{-1}$ while morphine inhibited $63.6 \%$ of the writhes when administered at a dose of $0.1 \mathrm{mg} \mathrm{kg}^{-1}$.

Compounds 17, 19, 29-31, (grayananes) and 33 (kalmane) produced antinociceptive effects at lower doses while showed toxic reactions at higher doses. Mice given higher doses showed reactions of nausea and convulsion, which is consistent with the clinical symptoms of "zhaoshanbai" poisoning. ${ }^{5-7}$ The results in this test and those reported previously revealed that among the antinociceptive components, grayananes and kalmanes are responsible for both antinociceptive and toxic effects. Their antinociceptive activity was positively correlated with the toxicity. ${ }^{8,13,30}$ Some kauranes and leucothanes also showed significant antinociceptive activity at relatively high doses, but no toxic reaction was observed. ${ }^{10,14}$ This fact suggests that they may have different mechanisms of action.

The preliminary analysis of the structures (present and reported) and their bioactivities revealed that the presence of sugar unit at C-3, C-6, or C-16 decreases the activity as well as the toxicity (as in 11/17, 10/19, 15/rhododecorumin I, rhodomicranoside E/rhodomicranone E) ${ }^{10,14}$ Compound 2 is more active than $\mathbf{1}$, which suggested that sugar unit at C-3 is likely to hinder activity to a lesser degree. Traditionally, "zhaoshanbai" was extracted by water decoction. Diterpenoid glycosides rather than the aglycones were the main components of the extract because of the polarity, which reduced the toxicity of the extract to a certain extent. ${ }^{31,32}$ However, in order to ensure clinical safety, the content of diterpenoid aglycones in extracts still needs to be monitored.

R. micranthum (zhaoshanbai) has also been widely used as an anti-inflammatory drug to alleviate the symptoms of upper respiratory inflammation. Therefore, the anti-inflammatory activities of the compounds 1-3, 7-11, 13-32, and 34-36 were evaluated by measuring inhibitory effects of LPS-induced NO production in BV2 cells. At $10 \mu \mathrm{M}$, compounds 9 and 26 displayed moderate activity with inhibition rates of $56.31 \%$ and $72.43 \%$, respectively (Fig. 5). At the same concentration, the inhibition rate of the positive control (curcumin) is $81.38 \%$.

\section{Conclusion}

A total of 36 diterpenoids, including fifteen new diterpenoid glycosides (1-15) and 21 known analogues were obtained from the leaves and twigs of $R$. micranthum. In the acetic acid-induced writhing test, compounds 17 and 19 showed significant antinociceptive activity at a dose of $3 \mathrm{mg} \mathrm{kg}^{-1}$ and compounds 2,6 and 32 showed significant antinociceptive activity at a dose of $10 \mathrm{mg} \mathrm{kg}^{-1}$. Grayananes and kalmanes such as 17, 19, 29-31, 33 are both antinociceptive and toxic components. In addition, micranthanoside IX (9) and rhodomicranoside F (26) showed moderate anti-inflammatory activity by reducing LPS-induced NO production in BV2 cells.

\section{Experimental section}

\section{General experimental procedures}

IR spectra were recorded using a Nicolet 5700 FT-IR spectrometer. Optical rotations were acquired via a Rudolph automatic polarimeter. HRESIMS analysis was carried out using an Agilent 6520 Accurate-Mass Q-TOF LC/MS spectrometer. NMR spectra were obtained using INOVA-500, Bruker AV600-III and INOVA SX-600 spectrometers. A Shimadzu LC-6AD instrument (SPD20A and RID-10A detectors) was used for preparative HPLC separations. Liquid chromatography was conducted using a YMC ODS column. A D101-type macroporous resin, Baoen Corporation (Cangzhou, China); Sephadex LH-20, GE Chemical Corporation (USA); silica gel and GF254 TLC plates, Jiangyou Corporation (Yantai, China); and ODS (50 $\mu \mathrm{m})$, Merck (Germany) were used for column chromatography (CC). TLC analyses were carried out on precoated silica gel GF254 plates, and spots were visualized under UV light (254 and $365 \mathrm{~nm}$ ) or by heating after spraying with a $5 \% \mathrm{CH}_{3} \mathrm{CH}_{2} \mathrm{OH}-\mathrm{H}_{2} \mathrm{SO}_{4}$ solution.

\section{Plant material}

Twigs and leaves of $R$. micranthum were collected from Yiyuan, Shandong Province in August 2014. The plant was authenticated by Prof. Peng Wan (Shandong University of Traditional Chinese Medicine). A voucher specimen (ID-s-2586) was deposited in the herbarium of Institute of Materia Medica, Chinese Academy of Medical Sciences.

\section{Extraction and isolation}

Twigs and leaves of $R$. micranthum $(107.5 \mathrm{~kg})$ were air-dried and extracted twice ( $2 \mathrm{~h}$ each time) with EtOH under reflux. The ethanol extracts were evaporated under reduced pressure, and the residue was suspended in water and then partitioned successively with petroleum ether, $\mathrm{CH}_{2} \mathrm{Cl}_{2}$, EtOAc, and $n$-BuOH. The EtOAc extract was separated using a macroporous resin column eluted sequentially with $70: 30,40: 60$, and $5: 95(\mathrm{v} / \mathrm{v})$ $\mathrm{H}_{2} \mathrm{O}-\mathrm{EtOH}$ solutions. Then, silica gel CC was used to separate the $60 \%$ EtOH fraction $(288.4 \mathrm{~g})$. The column was eluted with a step gradient of $\mathrm{CH}_{2} \mathrm{Cl}_{2} / \mathrm{MeOH}(20: 1,10: 1,5: 1$, and $1: 1, \mathrm{v} /$ v). Fractions $\mathrm{E}_{60} \mathrm{G}_{1}-\mathrm{E}_{60} \mathrm{G}_{9}$ were collected based on the TLC results. Fraction $\mathrm{E}_{60} \mathrm{G}_{2}$ was purified via semipreparative HPLC

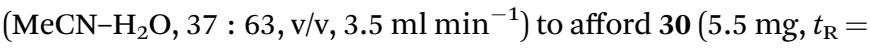


$37.5 \mathrm{~min}$ ). Fraction $\mathrm{E}_{60} \mathrm{G}_{3}$ was separated via a Sephadex $\mathrm{LH}-20$ column eluted with $\mathrm{MeOH}-\mathrm{H}_{2} \mathrm{O}(60: 40, \mathrm{v} / \mathrm{v})$ and yielded three fractions $\left(\mathrm{E}_{60} \mathrm{G}_{3} \mathrm{~L}_{1}-\mathrm{E}_{60} \mathrm{G}_{3} \mathrm{~L}_{3}\right) . \mathrm{E}_{60} \mathrm{G}_{3} \mathrm{~L}_{2}$ was purified via semipreparative HPLC $\left(\mathrm{MeCN}-\mathrm{H}_{2} \mathrm{O}, 25: 75, \mathrm{v} / \mathrm{v}, 3.5 \mathrm{ml} \mathrm{min}{ }^{-1}\right)$ to afford $17\left(72.4 \mathrm{mg}, t_{\mathrm{R}}=35.4 \mathrm{~min}\right), 29\left(20.8 \mathrm{mg}, t_{\mathrm{R}}=38.6\right.$ $\min ), 31\left(5.5 \mathrm{mg}, t_{\mathrm{R}}=40.9 \mathrm{~min}\right), 28\left(2.1 \mathrm{mg}, t_{\mathrm{R}}=15.7 \mathrm{~min}\right), 18$ $\left(9.9 \mathrm{mg}, t_{\mathrm{R}}=45.6 \mathrm{~min}\right), 27\left(52.3 \mathrm{mg}, t_{\mathrm{R}}=50.3 \mathrm{~min}\right)$. Fraction $\mathrm{E}_{60} \mathrm{G}_{6}$ was further separated using a Sephadex LH-20 column eluted with $\mathrm{MeOH}-\mathrm{H}_{2} \mathrm{O}(60: 40, \mathrm{v} / \mathrm{v}$ ) and yielded 2 fractions $\left(\mathrm{E}_{60} \mathrm{G}_{6} \mathrm{~L}_{1}-\mathrm{E}_{60} \mathrm{G}_{6} \mathrm{~L}_{2}\right)$. Fraction $\mathrm{E}_{60} \mathrm{G}_{6} \mathrm{~L}_{1}(20.0 \mathrm{~g})$ was separated using an MCI column and eluted with a step gradient of $\mathrm{MeOH} /$ $\mathrm{H}_{2} \mathrm{O}(40: 60,50: 50,60: 40,70: 30,80: 20$, and $100: 0, \mathrm{v} / \mathrm{v})$ to yield 6 fractions, $E_{60} G_{6} L_{1} M_{1}$ to $E_{60} G_{6} L_{1} M_{6}$. Fraction $E_{60} G_{6} L_{1} M_{2}$ was then separated via preparative $\mathrm{HPLC}\left(\mathrm{MeOH}-\mathrm{H}_{2} \mathrm{O}, 50: 50\right.$,

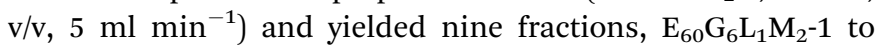
$\mathrm{E}_{60} \mathrm{G}_{6} \mathrm{~L}_{1} \mathrm{M}_{2}-9$. Fraction $\mathrm{M}_{2}-5$ was purified via semipreparative HPLC $\left(\mathrm{MeCN}-\mathrm{H}_{2} \mathrm{O}, 17: 83, \mathrm{v} / \mathrm{v}, 3.5 \mathrm{ml} \mathrm{min}^{-1}\right)$ to afford 24 $\left(17.5 \mathrm{mg}, t_{\mathrm{R}}=22.2 \mathrm{~min}\right), 25\left(23.2 \mathrm{mg}, t_{\mathrm{R}}=24.7 \mathrm{~min}\right)$, and 26 (8.7 $\mathrm{mg}, t_{\mathrm{R}}=28.7 \mathrm{~min}$ ). Fraction $\mathrm{M}_{2}-6$ was purified via semipreparative HPLC $\left(\mathrm{MeCN}-\mathrm{H}_{2} \mathrm{O}, 18: 82, \mathrm{v} / \mathrm{v}, 3.5 \mathrm{ml} \mathrm{min}^{-1}\right)$ to afford $16\left(6.0 \mathrm{mg}, t_{\mathrm{R}}=22.7 \mathrm{~min}\right)$. Fraction $\mathrm{M}_{2}-7$ was purified via semipreparative HPLC $\left(\mathrm{MeCN}-\mathrm{H}_{2} \mathrm{O}, 16: 84\right.$, v/v, $\left.3.5 \mathrm{ml} \mathrm{min}^{-1}\right)$ to afford $34\left(12.0 \mathrm{mg}, t_{\mathrm{R}}=36.9 \mathrm{~min}\right)$. Fraction $\mathrm{M}_{2}-8$ was purified via semipreparative HPLC $\left(\mathrm{MeCN}-\mathrm{H}_{2} \mathrm{O}, 25: 75, \mathrm{v} / \mathrm{v}, 3.5\right.$ $\left.\mathrm{ml} \mathrm{min}^{-1}\right)$ to afford $9\left(23.1 \mathrm{mg}, t_{\mathrm{R}}=15.1 \mathrm{~min}\right)$. Fraction $\mathrm{M}_{2}-9$ was purified via semipreparative $\mathrm{HPLC}\left(\mathrm{MeCN}-\mathrm{H}_{2} \mathrm{O}, 20: 80, \mathrm{v} / \mathrm{v}\right.$, $\left.3.5 \mathrm{ml} \mathrm{min}^{-1}\right)$ to afford $5\left(1.8 \mathrm{mg}, t_{\mathrm{R}}=20.4 \mathrm{~min}\right)$. Fraction $\mathrm{E}_{60} \mathrm{G}_{6} \mathrm{~L}_{1} \mathrm{M}_{3}$ was then separated via preparative HPLC (MeOH-

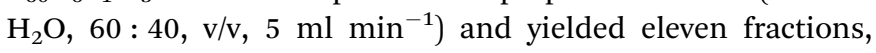
$\mathrm{E}_{60} \mathrm{G}_{6} \mathrm{~L}_{1} \mathrm{M}_{3}-1$ to $\mathrm{E}_{60} \mathrm{G}_{6} \mathrm{~L}_{1} \mathrm{M}_{3}-11$. Fraction $\mathrm{M}_{3}-5$ was purified via semipreparative HPLC $\left(\mathrm{MeCN}-\mathrm{H}_{2} \mathrm{O}, 25: 75, \mathrm{v} / \mathrm{v}, 3.5 \mathrm{ml} \mathrm{min}{ }^{-1}\right)$ to afford $19\left(7.0 \mathrm{mg}, t_{\mathrm{R}}=25.1 \mathrm{~min}\right)$ and $13\left(122.4 \mathrm{mg}, t_{\mathrm{R}}=28.7\right.$ min). Fraction $\mathbf{M}_{3}-6$ was purified via semipreparative HPLC

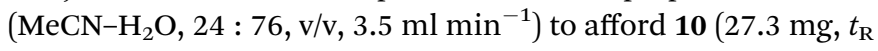
$=29.4 \mathrm{~min}), 6\left(40.1 \mathrm{mg}, t_{\mathrm{R}}=29.4 \mathrm{~min}\right)$, and $7\left(45.2 \mathrm{mg}, t_{\mathrm{R}}=29.4\right.$ min). Fraction $\mathrm{M}_{3}-8$ was purified via semipreparative HPLC $\left(\mathrm{MeCN}-\mathrm{H}_{2} \mathrm{O}, 27: 73, \mathrm{v} / \mathrm{v}, 3.5 \mathrm{ml} \mathrm{min}{ }^{-1}\right)$ to afford $3\left(2.2 \mathrm{mg}, t_{\mathrm{R}}=\right.$ 29.4 min). Fraction $\mathrm{M}_{3}-9$ was purified via semipreparative HPLC

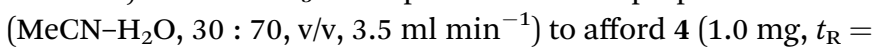
$25.4 \mathrm{~min})$. Fraction $\mathrm{M}_{3}-10$ was purified via semipreparative HPLC $\left(\mathrm{MeCN}-\mathrm{H}_{2} \mathrm{O}, 30: 70, \mathrm{v} / \mathrm{v}, 3.5 \mathrm{ml} \mathrm{min} \mathrm{m}^{-1}\right)$ to afford 8 $\left(5.7 \mathrm{mg}, t_{\mathrm{R}}=29.1 \mathrm{~min}\right)$ and $14\left(12.6 \mathrm{mg}, t_{\mathrm{R}}=40.8 \mathrm{~min}\right)$. Fraction $\mathrm{M}_{3}-11$ afforded $12\left(19.5 \mathrm{mg}, t_{\mathrm{R}}=58.0 \mathrm{~min}\right)$ without purification. Fraction $\mathrm{E}_{60} \mathrm{G}_{8}$ was further separated via a Sephadex LH-20 column eluted with $\mathrm{MeOH}-\mathrm{H}_{2} \mathrm{O}(60: 40, \mathrm{v} / \mathrm{v}$ ) and yielded four fractions $\left(\mathrm{E}_{60} \mathrm{G}_{8} \mathrm{~L}_{1}-\mathrm{E}_{60} \mathrm{G}_{8} \mathrm{~L}_{4}\right)$. Fraction $\mathrm{E}_{60} \mathrm{G}_{8} \mathrm{~L}_{3}$ afforded 32 (30.3 $\mathrm{mg}$ ). Fraction $\mathrm{E}_{60} \mathrm{G}_{8} \mathrm{~L}_{2}$ was separated via preparative HPLC

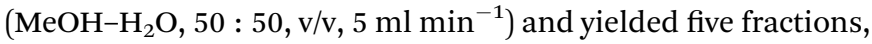
$\mathrm{E}_{60} \mathrm{G}_{8} \mathrm{~L}_{2}-1$ to $\mathrm{E}_{60} \mathrm{G}_{8} \mathrm{~L}_{2}-5$. Fraction $\mathrm{E}_{60} \mathrm{G}_{8} \mathrm{~L}_{2}-1$ afforded 23 (106.6 $\mathrm{mg})$. Fraction $\mathrm{E}_{60} \mathrm{G}_{8} \mathrm{~L}_{2}-3$ was purified via semipreparative HPLC

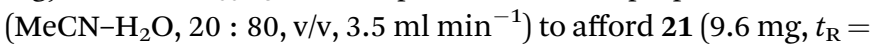
$41.2 \mathrm{~min})$. Fraction $\mathrm{E}_{60} \mathrm{G}_{8} \mathrm{~L}_{2}-4$ was purified via semipreparative HPLC $\left(\mathrm{MeCN}-\mathrm{H}_{2} \mathrm{O}, 20: 80, \mathrm{v} / \mathrm{v}, 3.5 \mathrm{ml} \mathrm{min}^{-1}\right)$ to afford 11 (9.8 $\left.\mathrm{mg}, t_{\mathrm{R}}=35.2 \mathrm{~min}\right)$.

The $30 \% \mathrm{EtOH}$ fraction of the macroporous resin column was also loaded on a silica gel column and eluted with a step gradient of $\mathrm{CH}_{2} \mathrm{Cl}_{2} / \mathrm{MeOH}(20: 1,10: 1,5: 1$, and $1: 1, \mathrm{v} / \mathrm{v})$.
Fractions $\mathrm{G}_{1}-\mathrm{G}_{9}$ were collected based on the results of TLC analysis. Fraction $\mathrm{E}_{30} \mathrm{G}_{5}$ was further purified via a Sephadex LH20 column to yield 2 fractions, $E_{30} G_{5} L_{1}$ and $E_{30} G_{5} L_{2}$. Fraction $\mathrm{E}_{30} \mathrm{G}_{5} \mathrm{~L}_{1}(37.7 \mathrm{~g})$ was separated via an MCI column and eluted with a step gradient of $\mathrm{MeOH} / \mathrm{H}_{2} \mathrm{O}(10: 90,30: 70,40: 60$, $50: 50,60: 40,70: 30$, and $100: 0, \mathrm{v} / \mathrm{v}$ ) to yield 5 fractions, $E_{30} G_{5} L_{1} M_{1}$ to $E_{30} G_{5} L_{1} M_{5}$. Fraction $E_{30} G_{5} L_{1} M_{3}$ was separated via ODS column and eluted with a step gradient of $\mathrm{MeOH} / \mathrm{H}_{2} \mathrm{O}$ (40:60, $50: 50,70: 30,80: 20$ and $100: 0$, v/v) to yield 5 fractions, $\mathrm{E}_{30} \mathrm{G}_{5} \mathrm{~L}_{1} \mathrm{M}_{3} \mathrm{O}_{1}$ to $\mathrm{E}_{30} \mathrm{G}_{5} \mathrm{~L}_{1} \mathrm{M}_{3} \mathrm{O}_{5}$. Fraction $\mathrm{E}_{30} \mathrm{G}_{5} \mathrm{~L}_{1} \mathrm{M}_{3} \mathrm{O}_{4}$ was purified via preparative HPLC to afford eight fractions, $\mathrm{E}_{30} \mathrm{G}_{5} \mathrm{~L}_{1} \mathrm{M}_{3} \mathrm{O}_{4}-1$ to $\mathrm{E}_{30} \mathrm{G}_{5} \mathrm{~L}_{1} \mathrm{M}_{3} \mathrm{O}_{4}-5$. $\mathrm{O}_{4}-1$ was purified via HPLC $\left(\mathrm{MeCN}-\mathrm{H}_{2} \mathrm{O}, 20: 80, \mathrm{v} / \mathrm{v}\right)$ to afford $35\left(2.1 \mathrm{mg}, t_{\mathrm{R}}=48.7 \mathrm{~min}\right)$. $\mathrm{O}_{4}-2$ was purified via $\mathrm{HPLC}\left(\mathrm{MeCN}-\mathrm{H}_{2} \mathrm{O}, 25: 75, \mathrm{v} / \mathrm{v}\right)$ to afford 1 $\left(8.4 \mathrm{mg}, t_{\mathrm{R}}=25.2 \mathrm{~min}\right.$ ) and $2\left(4.9 \mathrm{mg}, t_{\mathrm{R}}=32.9 \mathrm{~min}\right)$. Then, $\mathrm{E}_{30} \mathrm{G}_{5} \mathrm{~L}_{1} \mathrm{M}_{4}$ was purified via preparative HPLC $\left(\mathrm{MeCN}-\mathrm{H}_{2} \mathrm{O}\right.$, $20: 80, \mathrm{v} / \mathrm{v}$ ) to afford eight fractions, $\mathrm{E}_{30} \mathrm{G}_{5} \mathrm{~L}_{1} \mathrm{M}_{4}-1$ to $\mathrm{E}_{30} \mathrm{G}_{5} \mathrm{~L}_{1} \mathrm{M}_{4}{ }^{-}$ 8. $\mathrm{M}_{4}-3$ afforded $20\left(13.5 \mathrm{mg}, t_{\mathrm{R}}=15.5 \mathrm{~min}\right) . \mathrm{M}_{4}-4$ was purified via HPLC $\left(\mathrm{MeCN}-\mathrm{H}_{2} \mathrm{O}, 25: 75, \mathrm{v} / \mathrm{v}\right)$ to afford $15\left(7.7 \mathrm{mg}, t_{\mathrm{R}}=\right.$ $23.0 \mathrm{~min}) . \mathrm{M}_{4}-5$ was purified via $\mathrm{HPLC}\left(\mathrm{MeCN}-\mathrm{H}_{2} \mathrm{O}, 25: 75, \mathrm{v} / \mathrm{v}\right)$ to afford 22 ( $\left.8.9 \mathrm{mg}, t_{\mathrm{R}}=16.6 \mathrm{~min}\right) . \mathrm{M}_{4}-8$ was purified via HPLC $\left(\mathrm{MeCN}-\mathrm{H}_{2} \mathrm{O}, 30: 70, \mathrm{v} / \mathrm{v}\right)$ to afford $36\left(49.7 \mathrm{mg}, t_{\mathrm{R}}=34.6 \mathrm{~min}\right)$. Fraction $\mathrm{E}_{30} \mathrm{G}_{5} \mathrm{~L}_{1} \mathrm{M}_{5}$ was purified via $\mathrm{HPLC}\left(\mathrm{MeCN}-\mathrm{H}_{2} \mathrm{O}, 13: 87\right.$, $\mathrm{v} / \mathrm{v})$ to afford $33\left(6.1 \mathrm{mg}, t_{\mathrm{R}}=32.1 \mathrm{~min}\right)$.

Micranthanoside I (1). White powder; $[\alpha]_{\mathrm{D}}^{20}-49.1$ (c 0.53, $\mathrm{MeOH);} \mathrm{IR} v_{\max } 3368,2928,1700,1460,1357,1257,1159,1075$, 1041, 883, 857, 812, $634 \mathrm{~cm}^{-1} ;{ }^{1} \mathrm{H}$ and ${ }^{13} \mathrm{C}$ NMR data, see Tables 1 and 4; HRESIMS $m / z$ 505.2786 $[\mathrm{M}+\mathrm{Na}]^{+}$(calcd for $\mathrm{C}_{26} \mathrm{H}_{42} \mathrm{NaO}_{8}, 505.2772$ ).

Micranthanoside II (2). White powder; $[\alpha]_{\mathrm{D}}^{20}-83.3(c 0.48$, $\mathrm{MeOH})$; IR $v_{\max } 3350,2928,1701,1459,1357,1256,1230,1201$, 1163, 1074, 911, 888, 811, $635 \mathrm{~cm}^{-1} ;{ }^{1} \mathrm{H}$ and ${ }^{13} \mathrm{C}$ NMR data, see Tables 1 and 4; HRESIMS $m / z$ 505.2781 $[\mathrm{M}+\mathrm{Na}]^{+}$(calcd for $\mathrm{C}_{26} \mathrm{H}_{42} \mathrm{NaO}_{8}, 505.2772$ ).

Micranthanoside III (3). White powder; $[\alpha]_{\mathrm{D}}^{20}-58.1(c$ 0.02, $\mathrm{MeOH})$; IR $v_{\max } 3367,2962,1627,1549,1449$, 1378, 1077, 947, 903, $830 \mathrm{~cm}^{-1} ;{ }^{1} \mathrm{H}$ and ${ }^{13} \mathrm{C}$ NMR data, see Tables 1 and 4; HRESIMS $m / z 503.2623[\mathrm{M}+\mathrm{Na}]^{+}$(calcd for $\mathrm{C}_{26} \mathrm{H}_{40} \mathrm{NaO}_{8}$, 503.2615).

Micranthanoside IV (4). White powder; $[\alpha]_{\mathrm{D}}^{20}-50.0(c$ 0.01, $\mathrm{MeOH})$; IR $v_{\max } 3382,2930,2870,1630,1446,1363,1314,1256$, 1165, 1078, 1034, 929, 891, $759 \mathrm{~cm}^{-1} ;{ }^{1} \mathrm{H}$ and ${ }^{13} \mathrm{C}$ NMR data, see Tables 1 and 4; HRESIMS $m / z$ 485.2492 $[\mathrm{M}+\mathrm{Na}]^{+}$(calcd for $\mathrm{C}_{26} \mathrm{H}_{38} \mathrm{NaO}_{7}, 485.251$ ).

Micranthanoside V (5). White powder; $[\alpha]_{\mathrm{D}}^{20}+9.0(c$ 0.04, $\mathrm{MeOH);} \mathrm{IR} v_{\max } 3389,2924,1647,1598,1419,1076,911,852$, 805, $630 \mathrm{~cm}^{-1} ;{ }^{1} \mathrm{H}$ and ${ }^{13} \mathrm{C}$ NMR data, see Tables 1 and 4; HRESIMS $m / z$ 521.2722 $[\mathrm{M}+\mathrm{Na}]^{+}$(calcd for $\mathrm{C}_{26} \mathrm{H}_{42} \mathrm{NaO}_{9}$, 521.2721).

Micranthanoside VI (6). White powder; $[\alpha]_{\mathrm{D}}^{20}-58.7(c 0.06$, $\mathrm{MeOH})$; IR $v_{\max } 3380,2937,2869,1633,1548,1447,1046,1379$, 1307, 1266, 1156, 1073, 1034, 915, 890, $828 \mathrm{~cm}^{-1} ;{ }^{1} \mathrm{H}$ and ${ }^{13} \mathrm{C}$ NMR data, see Tables 1 and 4; HRESIMS $m / z$ 487.2676 [M+Na] $]^{+}$ (calcd for $\mathrm{C}_{26} \mathrm{H}_{40} \mathrm{NaO}_{7}, 487.2666$ ).

Micranthanoside VII (7). White powder; $[\alpha]_{\mathrm{D}}^{20}-34.2(c 0.06$, $\mathrm{MeOH})$; IR $v_{\max } 3379,2937,1728,1677,1549,1375,1306,1243$, 1201, 1080, 1048, 885, $643 \mathrm{~cm}^{-1} ;{ }^{1} \mathrm{H}$ and ${ }^{13} \mathrm{C}$ NMR data, see 
Tables 1 and 4; HRESIMS $m / z$ 487.2671 [M $+\mathrm{Na}]^{+}$(calcd for $\left.\mathrm{C}_{26} \mathrm{H}_{40} \mathrm{NaO}_{7}, 487.2666\right)$.

Micranthanoside VIII (8). White powder; $[\alpha]_{\mathrm{D}}^{20}-17.6(c 0.06$, $\mathrm{MeOH})$; IR $v_{\max } 3375,2938,2873,1641,1549,1448,1379,1306$, 1158, 1079, 1041, 940, 898, 858, 830, 769, 624, $536 \mathrm{~cm}^{-1} ;{ }^{1} \mathrm{H}$ and ${ }^{13} \mathrm{C}$ NMR data, see Tables 2 and 4; HRESIMS $m / z$ 505.2788 [M + $\mathrm{Na}]^{+}$(calcd for $\mathrm{C}_{26} \mathrm{H}_{42} \mathrm{NaO}_{8}, 505.2772$ ).

Micranthanoside IX (9). White powder; $[\alpha]_{\mathrm{D}}^{20}-48.6$ (c 0.06, $\mathrm{MeOH})$; IR $v_{\max } 3407,2937,1628,1448,1382,1264,1158,1077$, 1041, 950, 898, 858, $639 \mathrm{~cm}^{-1} ;{ }^{1} \mathrm{H}$ and ${ }^{13} \mathrm{C}$ NMR data, see Tables 2 and 4; HRESIMS $m / z$ 505.2775 $[\mathrm{M}+\mathrm{Na}]^{+}$(calcd for $\left.\mathrm{C}_{26} \mathrm{H}_{42} \mathrm{NaO}_{8}, 505.2772\right)$.

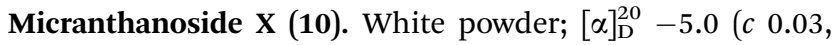
$\mathrm{MeOH})$; IR $v_{\max } 3382,2933,1637,1450,1384,1222,1080,1035$, 916, 890, 859, 827, $647 \mathrm{~cm}^{-1} ;{ }^{1} \mathrm{H}$ and ${ }^{13} \mathrm{C}$ NMR data, see Tables 2 and 4 ; HRESIMS $m / z$ 505.2766 $[\mathrm{M}+\mathrm{Na}]^{+}$(calcd for $\mathrm{C}_{26} \mathrm{H}_{42} \mathrm{NaO}_{8}$, 505.2772).

Micranthanoside XI (11). White powder; $[\alpha]_{\mathrm{D}}^{20}-27.8(c \quad 0.2$, $\mathrm{MeOH})$; IR $v_{\max } 3368,2927,1701,1460,1357,1163,1074,1031$, 911, 888, 811, $635 \mathrm{~cm}^{-1} ;{ }^{1} \mathrm{H}$ and ${ }^{13} \mathrm{C}$ NMR data, see Tables 2 and 4 HRESIMS $m / z 503.2612[\mathrm{M}+\mathrm{Na}]^{+}$(calcd for $\mathrm{C}_{26} \mathrm{H}_{40} \mathrm{NaO}_{8}$, 503.2615).

Micranthanoside XII (12). White powder; $[\alpha]_{\mathrm{D}}^{20}+66.0(c 0.05$, $\mathrm{MeOH})$; IR $v_{\max } 3393,2926,2850,1645,1596,1468,1453,1417$, 1384, 1261, 1157, 974, 633, $546 \mathrm{~cm}^{-1} ;{ }^{1} \mathrm{H}$ and ${ }^{13} \mathrm{C}$ NMR data, see Tables 3 and 4; HRESIMS $m / z 521.2708[\mathrm{M}+\mathrm{Na}]^{+}$(calcd for $\left.\mathrm{C}_{26} \mathrm{H}_{42} \mathrm{NaO}_{9}, 521.2721\right)$.

Micranthanoside XIII (13). White powder; $[\alpha]_{\mathrm{D}}^{20}-92.0(c 0.25$, $\mathrm{MeOH})$; IR $v_{\max } 3557,3526,3481,3330,2942,2885$, 1716, 1659, 1461, 1434, 1386, 1102, 1076, 1042, 988, 943, 640, $601 \mathrm{~cm}^{-1} ;{ }^{1} \mathrm{H}$ and ${ }^{13} \mathrm{C}$ NMR data, see Tables 3 and 4; HRESIMS $m / z$ 521.2719 $[\mathrm{M}+\mathrm{Na}]^{+}$(calcd for $\mathrm{C}_{26} \mathrm{H}_{42} \mathrm{NaO}_{9}, 521.2721$ ).

Micranthanoside XIV (14). White powder; $[\alpha]_{\mathrm{D}}^{20}-44.4(c 0.08$, $\mathrm{MeOH);} \mathrm{IR} v_{\max } 3511,3321,2947,2874,1698,1623,1462,1442$, 1387, 1269, 1104, 1070, 1020, 997, 959, 855, 645, 574, $552 \mathrm{~cm}^{-1}$; ${ }^{1} \mathrm{H}$ and ${ }^{13} \mathrm{C}$ NMR data, see Tables 3 and 4; HRESIMS $\mathrm{m} / \mathrm{z}$ 521.2711 [M + Na $]^{+}$(calcd for $\mathrm{C}_{26} \mathrm{H}_{42} \mathrm{NaO}_{9}, 521.2721$ ).

Micranthanoside XV (15). White powder; $[\alpha]_{\mathrm{D}}^{20}-69.8(c 0.07$, $\mathrm{MeOH})$; IR $v_{\max } 3396,2935,2872,1701,1643,1447,1381,1299$, 1202, 1159, 1077, 1030, 991, 928, 886, 844, 595, $579 \mathrm{~cm}^{-1} ;{ }^{1} \mathrm{H}$ and ${ }^{13} \mathrm{C}$ NMR data, see Tables 3 and 4; HRESIMS $m / z 503.2615$ $[\mathrm{M}+\mathrm{Na}]^{+}$(calcd for $\mathrm{C}_{26} \mathrm{H}_{0} \mathrm{NaO}_{8}, 503.2615$ ).

\section{Acid hydrolysis and GC analysis}

The configuration of the sugar moiety was established according to a published method. ${ }^{33}$ The compounds were dissolved in $\mathrm{MeOH}(2 \mathrm{ml})$ and then added to $2 \mathrm{~N} \mathrm{HCl}(2 \mathrm{ml})$. The solution was heated at $90{ }^{\circ} \mathrm{C}$ for $12 \mathrm{~h}$. The reaction mixture was evaporated and partitioned with EtOAc and $\mathrm{H}_{2} \mathrm{O}$. The aqueous layer was concentrated to dryness, dissolved in dry pyridine and reacted with L-cysteine methyl ester hydrochloride $(2 \mathrm{mg})$ at $80{ }^{\circ} \mathrm{C}$ for $1 \mathrm{~h}$. After removal of the solvent, $\mathrm{N}$-trimethylsilylimidazole $(1 \mathrm{ml})$ was added, and the mixture was heated at $80^{\circ} \mathrm{C}$ for $0.5 \mathrm{~h}$. The residue partitioned into $n$-hexane and $\mathrm{H}_{2} \mathrm{O}$, and the $n$ hexane part was analyzed on a GC system equipped with an FID (detector temperature, $300{ }^{\circ} \mathrm{C}$ ). Chromatography conditions: injection temperature, $280{ }^{\circ} \mathrm{C}$; column, HP-5 $(60 \mathrm{~m} \times 0.32 \mathrm{~mm}$ $\times 0.25 \mu \mathrm{m})$; initial column temperature, $200{ }^{\circ} \mathrm{C}$; column temperature increased to $280{ }^{\circ} \mathrm{C}\left(10{ }^{\circ} \mathrm{C} \min ^{-1}\right)$ and kept at $280{ }^{\circ} \mathrm{C}$ for $40 \mathrm{~min}$ under $\mathrm{N}_{2}$ carrier gas $\left(1.8 \mathrm{ml} \mathrm{min}^{-1}\right)$.

\section{Animals}

Male Kunming mice (16-20 g) were housed for three days prior to use. All animal care and experimental procedures were in accordance with the guidelines of the National Institutes of Health (NIH), and the experimental procedures were approved by the Ethics Committee of Institute of Materia Medica, Chinese Academy of Medical Sciences and Peking Union Medical College (Beijing, China).

\section{Acetic acid-induced writhing tests}

Kunming mice (eight per group) were used in the tests. Control mice received $0.9 \% \mathrm{NaCl}\left(10 \mathrm{ml} \mathrm{kg}^{-1}\right.$, ip), and the test mice received aqueous solutions $\left(10,3,1,0.3\right.$, or $0.1 \mathrm{mg} \mathrm{kg}^{-1}$, ip; injection volume: $10 \mathrm{ml} \mathrm{kg}{ }^{-1}$ ) with a solution concentration of $1 \mathrm{mg} \mathrm{ml}^{-1}, 0.3 \mathrm{mg} \mathrm{ml}^{-1}, 0.1 \mathrm{mg} \mathrm{ml}^{-1}, 0.03 \mathrm{mg} \mathrm{ml}^{-1}$, or $0.01 \mathrm{mg}$ $\mathrm{ml}^{-1}$. Compounds 17-19, 29-31, and 33 utilized 1\% Tween 80 as hydrotropic agent. Fifteen minutes later, 1\% v/v HOAc solution $(0.1 \mathrm{ml} / 10 \mathrm{~g})$ was administered to the mice by intraperitoneal injection. The number of writhing events for each mouse was counted for $15 \mathrm{~min}$.

\section{Anti-inflammatory activity assays}

Compounds were tested for their anti-inflammatory activity by measuring inhibitory effects of LPS-induced NO production in BV2 cells. Curcumin was used as the positive control. The BV2 macrophage cell line was obtained from the Cell Culture Center at the Institute of Basic Medical Sciences, Peking Union Medical College. LPS was bought from Sigma-Aldrich company. After preincubation for $24 \mathrm{~h}$ in a 96-well plate, the cells were treated with the test compounds $\left(10^{-5} \mathrm{~mol} \mathrm{~L}^{-1}\right)$, then stimulated with LPS for $24 \mathrm{~h}$. The production of NO was determined via measuring the concentration of nitrite in the culture supernatant. $\mathrm{NaNO}_{2}$ was utilized to generate a standard curve. The absorbances at $550 \mathrm{~nm}$ were measured.

\section{Conflicts of interest}

The authors declare no competing financial interest.

\section{Acknowledgements}

This work was supported by grants from the National Natural Science Foundation of China (No. 21572274, 21732008, and 81630094) and the CAMS Innovation Fund for Medical Sciences (No. 2016-I2M-3-012).

\section{Notes and references}

1 D. J. Newman and G. M. Cragg, J. Nat. Prod., 2012, 75, 311. 2 D. J. Newman and G. M. Cragg, J. Nat. Prod., 2016, 79, 629. 
3 A. L. Harvey, R. A. Edrada-Ebel and R. J. Quinn, Nat. Rev. Drug Discovery, 2015, 14, 111.

4 Chinese Materia Medica Compilation Commission, Chinese Materia Medica, 1986, vol. 16. p. 5264.

5 Jinan People's Pharmaceutical Factory, Chin. Tradit. Herb. Drugs, 1970, 4, 30.

6 Zhaoshanbai Clinical Cooperative Group of Beijing Military Region, People Mil. Surg., 1975, vol. 10, p. 38.

7 Xiyang Gaoluo District Hospital, Shanxi Med. J., 1978, 2, 10.

8 Coronary Heart Disease Research Group of Tianjin Institute for Drug Control, Chin. Tradit. Herb. Drugs, 1976, 5, 12.

9 Y. Li, Y. B. Liu, J. J. Zhang, Y. Liu, S. G. Ma, J. Qu, H. N. Lv and S. S. Yu, J. Nat. Prod., 2015, 78, 2887.

10 Y. X. Zhu, Z. X. Zhang, H. M. Yan, D. Lu, H. P. Zhang, L. Li, Y. B. Liu and Y. Li, J. Nat. Prod., 2018, 81, 1183.

11 C. S. Niu, Y. Li, Y. B. Liu, S. G. Ma, L. Li, J. Qu and S. S. Yu, Tetrahedron, 2016, 72, 44.

12 C. S. Niu, Y. Li, Y. B. Liu, S. G. Ma, F. Liu, S. Xu, X. J. Wang, S. Liu, R. B. Wang, J. Qu and S. S. Yu, RSC Adv., 2017, 69, 43921.

13 N. Sun, Y. Zhu, H. F. Zhou, J. F. Zhou, H. Q. Zhang, M. K. Zhang, H. Zeng and G. M. Yao, J. Nat. Prod., 2018, 81, 2673.

14 N. Sun, Y. Qiu, J. J. Liu, H. Q. Zhang, Q. H. Zhang, M. K. Zhang, G. J. Zheng, C. Zhang and G. M. Yao, Phytochemistry, 2019, 158, 1.

15 X. C. Li, D. Ferreira and Y. Q. Ding, Curr. Org. Chem., 2010, 14, 1678.

16 L. Q. Wang, S. N. Chen, K. F. Chen, C. J. Li and G. W. Qin, Phytochemistry, 2000, 54, 847.

17 T. Kaiya and J. Sakakibara, Chem. Pharm. Bull., 1985, 33, 4637.
18 M. K. Zhang, Y. Y. Xie, G. Q. Zhan, L. Lei, P. H. Shu, Y. L. Chen, Y. B. Xue, Z. H. Luo, Q. Wan, G. M. Yao and Y. H. Zhang, Phytochemistry, 2015, 117, 107.

19 J. Sakakibara, N. Shirai, T. Kaiya and H. Nakata, Phytochemistry, 1979, 18, 135.

20 L. Q. Wang, B. Y. Ding, W. M. Zhao and G. W. Qin, Chin. Chem. Lett., 1998, 9, 465.

21 J. W. Burke and R. W. Doskotch, J. Nat. Prod., 1990, 53, 131.

22 J. Sakakibara, N. Shirai, T. Kaiya and Y. Litaka, Phytochemistry, 1980, 19, 1495.

23 S. F. Elnaggar, R. W. Doskotch, T. M. Odell and L. Girard, J. Nat. Prod., 1980, 43, 617.

24 T. Ohta and H. Hikino, Magn. Reson. Chem., 2010, 12, 445.

25 J. Katakawa, T. Tetsumi, T. Terai, M. Katai, K. Sakaguchi and M. Sato, J. Chem. Crystallogr., 2000, 30, 573.

26 H. Hikino, T. Ohta, S. Koriyama, Y. Hikino and T. Takemoto, Chem. Pharm. Bull., 1971, 19, 1289.

27 I. Sakamoto, K. Yamasaki and O. Tanaka, Chem. Pharm. Bull., 2008, 25, 3437.

28 J. W. Burke, R. W. Doskotch, C. Z. Ni and J. Clardy, J. Am. Chem. Soc., 1988, 111, 5831.

29 J. Sakakibara, N. Shirai and T. Kaiya, Phytochemistry, 1981, 20, 1744 .

30 Y. Li, Y. X. Zhu, Z. X. Zhang, Y. L. Liu, Y. B. Liu, J. Qu, S. G. Ma, X. J. Wang and S. S. Yu, Tetrahedron, 2018, 74, 693.

31 X. Li, Y. F. Liu, K. M. Ye, W. X. Yuan and Y. J. Han, J. Shenyang Pharm. Univ., 1978, 9, 17.

32 F. Y. Fu, Y. Z. Zhang, T. M. Shang, S. R. Luo, B. Y. Zhang and Z. J. Wang, Chin. Pharm. J., 1980, 15, 13.

33 S. Hara, H. Okabe and K. Mihashi, Chem. Pharm. Bull., 1981, 35,501 . 